Working Paper/Document de travail 2014-6

\title{
A Policy Model to Analyze Macroprudential Regulations and Monetary Policy
}

by Sami Alpanda, Gino Cateau and Césaire Meh 
Bank of Canada Working Paper 2014-6

February 2014

\title{
A Policy Model to Analyze Macroprudential Regulations and Monetary Policy
}

by

\author{
Sami Alpanda, ${ }^{1}$ Gino Cateau ${ }^{1}$ and Césaire $M^{2}{ }^{2}$ \\ ${ }^{1}$ Canadian Economic Analysis Department \\ 2Financial Stability Department \\ Bank of Canada \\ Ottawa, Ontario, Canada K1A 0G9 \\ salpanda@bankofcanada.ca \\ gcateau@bankofcanada.ca \\ cmeh@bankofcanada.ca
}

Bank of Canada working papers are theoretical or empirical works-in-progress on subjects in economics and finance. The views expressed in this paper are those of the authors. No responsibility for them should be attributed to the Bank of Canada. 


\section{Acknowledgements}

We thank Robert Amano, Greg Bauer, Julien Bengui, Jean Boivin, Fabia Carvalho, Marcos Castro, Larry Christiano, Jose Dorich, Michael Johnston, Magnus Jonsson, Nobu Kiyotaki, Sharon Kozicki, Oleksiy Kryvtsov, Rhys Mendes, Enrique Mendoza, Tommasso Monacelli, Stephen Murchison, Brian Peterson, Alessandro Rebucci, Yasuo Terajima, Alexander Ueberfeldt, Yahong Zhang, Yang Zhang, and seminar participants at the Bank of Canada, EcoMod 2013 in Prague, BIS CCA Research Network 2013 in Mexico City, BoC-BoJ Workshop in Tokyo, and Bank of Korea Conference in Seoul for comments. All errors are ours. 


\begin{abstract}
We construct as mall-open-economy, New Keynesian dynamic stochastic generalequilibrium model with real-financial linkages to analyze the effects of financial shocks and macroprudential policies on the Canadian economy. Our model has four key features. First, it a llows for non-trivial interactions between the balance sheets of households, firms and banks within a unified framework. Second, it incorporates a risk-taking channel by allowing the risk appetite of investors to depend on aggregate economic activity and funding conditions. Third, it incorporates long-term debt by allowing households and businesses to pay back their stock of debt over multiple periods. Fourth, it incorporates targeted and broader macroprudential instruments to analyze the interaction between macroprudential and monetary policy. The model also features nominal and real rigidities, and is calibrated to match dynamics in Canadian macroeconomic and financial data. We study the transmission of monetary policy and financial shocks in the model economy, and analyze the effectiveness of various policies in simultaneously achieving macroeconomic and financial stability. We find that, in terms of reducing household debt, more targeted tools such as loan-to-value regulations are the most effective and least costly, followed by bank capital regulations and monetary policy, respectively.
\end{abstract}

JEL classification: E44, F41, E32, E17

Bank classification: Economic models; Financial system regulation and policies

\title{
Résumé
}

Les auteurs proposent un modèle d'équilibre général dynamique et stochastique de type néo-keynésien intégrant des liens entre les sphères réelle et financière d'une petite économie ouverte. Leur modèle sert à analyser différents scénarios relatifs à l'incidence de chocs financiers et de politiques macroprudentielles sur l'économie canadienne. Celuici s'articule autour de quatre points. Premièrement, dans un cadre d'analyse unifié, il donne lieu à des interactions importantes entre les actifs et passifs respectifs des ménages, des entreprises et des banques. Ensuite, il introduit un canal de prise de risques en posant que l'appétit des investisseurs pour le risque dépend de l'activité agrégée ainsi que de l'ensemble des conditions de financement. Troisièmement, le modèle incorpore la notion de dette à long terme en permettant aux ménages d'étaler le remboursement de leur dette sur de multiples périodes. Enfin, il tient compte d'un ensemble d'instruments de politique macroprudentielle-aussi bien des instruments ciblés que des instruments plus généraux - afin d'apprécier les interactions existant entre la politique macroprudentielle et la politique monétaire. Le modèle repose notamment sur des rigidités réelles et nominales dans la formation des prix et des salaires et il est étalonné afin de reproduire la dynamique des données macroéconomiques et financières du $\mathrm{C}$ anada. Les auteurs étudient la transmission de la politique monétaire et des chocs financiers au sein de l'économie définie par le modèle, et ils analysent l'efficacité avec laquelle différentes politiques parviennent à atteindre de façon simultanée la stabilité sur les plans 
macroéconomique et financier. De cette analyse, il ressort que les instruments ciblés, tels que la réglementation du rapport prêt-valeur, sont les plus efficaces et les moins coûteux pour réduire l'endettement des ménages canadiens, loin devant les autres instruments plus généraux considérés que sont la réglementation des fonds propres des banques et la politique monétaire.

Classification JEL : E44, F41, E32, E17

Classification de la Banque : Modèles économiques; Réglementation et politiques relatives au système financier 


\section{Introduction}

In response to the global financial crisis, central banks in many countries have been refining their policy models to better account for the interactions between the real economy and the financial sector. This growing effort reflects mainly two considerations. First, there is now a better appreciation that macroeconomic and financial stability are inextricably linked, and that pursuing one objective without due regard for the other risks achieving neither. Indeed, the crisis demonstrated that not only can the financial system be a source of shocks that severely impinge on the economy, it can also significantly amplify and propagate shocks originating elsewhere. Therefore, when assessing the proper stance of monetary policy in response to developments in the real economy, financial stability considerations should not be ignored. Second, given that macroeconomic and financial stability are closely linked, there is also a better appreciation that monetary, fiscal and macroprudential policies may need to be used jointly to ensure both macroeconomic and financial stability. As a result, there is a need to better understand how these different policies interact, what trade-offs they give rise to, and the appropriate mix of policies that are required to achieve a good balance between macroeconomic and financial stability. In particular, there is a need to evaluate the effectiveness of such policies in achieving financial stability, as well as their implications for the ability of monetary policy to stabilize the economy over the short run.

In this paper, we construct a policy model for Canada to analyze real-financial linkages within a unified framework. ${ }^{1}$ Our model has four key features. First, it allows for non-trivial interactions between the balance sheets of households, firms and banks. As a result, the model captures how endogenous changes in the balance-sheet positions of households, firms and banks affect funding and lending conditions, and in turn real variables. Second, it incorporates a risk-taking channel by allowing the risk appetite of investors to depend on aggregate economic activity and funding conditions. Third, it incorporates long-term debt by allowing households and businesses to pay back their stock of debt over multiple periods. Fourth, it incorporates targeted macroprudential instruments (regulatory LTV) and broader tools (capital requirements), which allows us to analyze the interaction between macroprudential and monetary policy.

More specifically, our model is a medium-scale small-open-economy New Keynesian dynamic stochastic general-equilibrium (DSGE) model with real, nominal and financial frictions. It features four key agents: patient households (savers), banks (intermediaries), impatient households and entrepreneurs (borrowers). Due to financial frictions modelled similar to Curdia and Woodford (2011),

\footnotetext{
${ }^{1}$ The Bank of Canada has already made significant progress in terms of refining existing models, and developing new models, with real-financial linkages to better understand the nexus between monetary policy and financial stability. For instance, Dorich et al. (2013) have introduced exogenous term and risk spreads, as well as a housing sector and household wealth, in ToTEM, the main projection model of the Bank of Canada. Meh and Moran (2010), Christensen and Dib (2008), Dib (2010a, 2010b), and Christensen et al. (2011) incorporate financial features that capture the effects of banks' and borrowers' net worth positions on risk premia for business loans. Basant Roi and Mendes (2007), Christensen et al. (2009), and Christensen and Meh (2011) incorporate household balance sheets and debt in models featuring the housing market to study the effects of exuberance in housing markets and loan-to-value (LTV) ratio regulations (see the Bank of Canada Review (Summer 2011) special issue on real-financial linkages for a brief summary of these models).
} 
Bernanke et al. (1999), and Iacoviello (2013), banks face a spread on their short-term funding rate based on their capital position. Similarly, borrowers face spreads based on their leverage positions when they receive bank loans to finance their housing and capital purchases. Bank capital and LTV regulations affect the economy primarily through their effects on these funding and lending spreads. Bank loans to households and entrepreneurs are modelled as long-term bonds paying decaying coupon payments, as in Alpanda and Dorich (2013), Woodford (2001) and Chen et al. (2012). Elements of the risk-taking channel are introduced through the effects of aggregate economic activity and funding conditions on the risk appetite of savers. Thus, in expansions when funding liquidity is plentiful, the risk appetite of investors increases, inducing them to rebalance their portfolios toward riskier assets. This gives rise to an additional amplification mechanism: favorable shocks are further reinforced by the increased risk appetite of savers. This leads to an increase in asset prices above and beyond what we would otherwise observe.

The model also features nominal and real rigidities that are now commonplace in the literature, such as price and wage stickiness, inflation indexation, adjustment costs in investment, and habit formation in consumption, as in Christiano et al. (2005), Murchison and Rennison (2006), and Smets and Wouters (2007). Further, we incorporate small-open-economy aspects along the lines of Gali and Monacelli (2005), Gertler et al. (2007), and Adolfson et al. (2008). In particular, we allow for a more flexible form of the uncovered interest parity (UIP) condition, and take into account the partial pass-through of exchange rate movements to import and export prices. The model is calibrated to match dynamics in Canadian macroeconomic and financial data.

To illustrate how the model can be helpful for policy analysis, we use it to study the costs and effectiveness of different policy tools in reducing household indebtedness in Canada. This issue is of particular relevance for the Canadian economy since, with the policy rate low for a long time as a result of global external headwinds, Canada's household debt-to-income ratio has reached record high levels, posing a potential risk to financial stability (see Figure 1). Using our model, we find that targeted policies such as LTV regulations are the most effective and least costly, followed by bank capital regulations and monetary policy, respectively. In particular, a 5 percentage point (pp) tightening in regulatory LTV decreases household debt by about 7.6 per cent at the peak, while its output impact is about 0.7 per cent. In contrast, a 1 pp increase in capital requirements reduces household debt by about 1.4 per cent and reduces output by about 0.35 per cent at the peak. Hence, an increase of about $2 \mathrm{pp}$ in bank capital would have the same impact on output as a 5 pp reduction in LTV, but its impact on household debt would be about half of LTV at the peak. Similarly, a 100 basis point (bp) temporary increase in the policy rate reduces household debt by about 0.5 per cent at the peak, but this comes at an output cost of about 0.4 per cent, offering an even worse trade-off than capital requirements in terms of reducing household debt.

The next section surveys the main themes in the recent literature on real-financial linkages. Section 3 introduces the model, and section 4 discusses the calibration of model parameters. The main implications of the model are discussed in section 5, and section 6 concludes. 


\section{Main Themes in the Recent Literature on Real-Financial Link- ages}

In this section, we review the main strands of the literature that our model builds on. The recent literature emphasizes three main channels through which financial developments impact the real economy: (i) the balance-sheet channel, (ii) the bank capital channel, and (iii) the role of excessive risk taking arising from the ample availability of liquidity and associated externalities, the stance of monetary policy, or irrational behavior.

\section{$2.1 \quad$ Balance-sheet channel}

The balance-sheet channel posits that the leverage position of borrowers is key for their borrowing conditions, and shocks are amplified through their effects on asset prices and the net worth position of borrowers. There are mainly two types of models in this literature: the agency cost model (Carlstrom and Fuerst, 1997; Bernanke et al., 1999) and the collateral model (Kiyotaki and Moore, 1997; Iacoviello, 2005).

The agency cost model features asymmetric information between banks and borrowers. In particular, borrowers are subject to idiosyncratic shocks on their capital quality, which leads some of them to default on their loans. In equilibrium, defaults are increasing in borrower leverage; thus, banks charge a risk premium on loans based on the leverage position of borrowers. An increase in asset prices strengthens the borrowers' balance sheets by increasing their net worth and reducing their leverage. This in turn reduces the agency costs faced by lenders and the cost of debt faced by borrowers, which stimulates borrowing and investment activity above and beyond the effects of the shock in the absence of asset-price movements. This effect is called the financial accelerator in the literature.

In the collateral model, assets are used as collateral against borrowing, as well as provide consumption services, or are used as an input in production. An increase in asset prices raises the collateral value of these assets, which relaxes the borrowing constraints of households and firms, and amplifies the original effects of the shock (i.e., the financial accelerator). Unlike the agency cost model, the collateral model does not feature an endogenous lending spread, but the tightness with which the borrowing constraint binds provides a shadow cost between the cost of capital faced by borrowers and the risk-free rate. ${ }^{2}$

\subsection{Bank capital channel}

The balance-sheet channel discussed above focuses on how the balance-sheet position of borrowers influences their borrowing conditions and can amplify shocks. The bank capital channel, in contrast,

\footnotetext{
${ }^{2}$ The literature on the financial accelerator is too vast to list here; see Gilchrist et al. (2009), Christiano et al. (2010), and the references listed therein. For specific applications to housing, see Aoki et al. (2004), Iacoviello (2005), Basant Roi and Mendes (2007), Iacoviello and Neri (2010), Christensen and Meh (2011), Chatterjee and Eyigungor (2011), and Alpanda and Zubairy (2013).
} 
focuses on the balance-sheet position of the lenders (e.g., banks), and how this can impact their funding conditions and loan supply. In particular, better-capitalized banks are able to attract funds at cheaper rates, which allows them to lend to households and businesses at reduced rates. This channel is all the more relevant in a world where banks increasingly fund themselves through marketbased wholesale funding, as opposed to retail deposits. Retail deposits are by-and-large insured by the government, and therefore are not that sensitive to the capital position of banks. On the other hand, problems related to banks' solvency and liquidity can quickly lead to sharp increases in wholesale funding rates, and dry up banks' short-term funding sources. This would force banks to liquidate assets prematurely and cut back on new loans, with adverse effects on the financial system and macroeconomic conditions.

The models in this literature typically feature a moral hazard problem between savers and banks. In the double moral hazard model of Holmstrom and Tirole (1997), Chen (2001), and Meh and Moran (2010), households would not deposit funds to banks unless banks partly use their own capital to fund their lending. If banks do not have sufficient "skin in the game," they are not induced to monitor their borrowers, which in turn leads borrowers to divert funds away from projects for their own gain. Thus, bank capital plays a crucial role in determining bank funding and lending conditions. In the model, the required return on bank capital is assumed to be higher than the deposit rate; thus, when banks are required to commit more capital through regulations, the cost of debt for borrowers also increases. Similarly, in the endogenous borrowing constraint model of Gertler and Karadi (2011) and Gertler and Kiyotaki (2010), bankers can divert funds for their own benefit instead of financing the capital purchases of entrepreneurs. This moral hazard leads to an endogenous borrowing constraint for banks; the availability of bank capital relaxes this constraint, and eases funding conditions for banks.

Aikman and Paustian (2006) and Davis (2010) extend the agency cost model of Bernanke et al. (1999) to include asymmetric information between savers and banks. In particular, banks are subject to idiosyncratic shocks on their assets, which leads some of them to default on their depositors. In equilibrium, defaults are increasing in the leverage position of the banks; thus, savers charge a risk premium on short-term bank funding based on the leverage position of banks. Thus, this model features two financial accelerators (between savers and banks, and between banks and borrowers), which leads to the so-called adverse feedback loop mechanism, where deterioration in borrower balance sheets also leads to deterioration in bank balance sheets. This generates comovement between bank lending and bank funding spreads, and exacerbates the adverse effects of asset-price declines in recessions. ${ }^{3}$

A moderating factor in the strength of the bank capital channel is the speed with which assetprice fluctuations are passed through to bank capital. The asset side of bank balance sheets, especially of larger banks, is now dominated by holdings of financial securities linked directly and

\footnotetext{
${ }^{3}$ See Iacoviello (2013) for a double collateral constraint model to capture the same mechanism. The literature on the bank capital channel also includes models that feature bank capital based solely on the existence of regulatory constraints (see Van den Heuvel, 2008; Gerali et al., 2010).
} 
indirectly to corporate and real estate values. Asset-price fluctuations, especially with mark-tomarket accounting, thus rapidly and directly affect the net worth of banks. With more traditional loans, the effects of asset prices on bank capital are more gradual, given that borrowers default with a lag, and it takes time for banks to write off these loans from their balance sheets.

\subsection{Liquidity, risk taking and exuberance}

As alluded to earlier, wholesale funds, as opposed to retail deposits, have become the main source of banks' funding at the margin, especially for large and systemically important banks (Adrian and Shin, 2010; Kiyotaki and Moore, 2012). The prevalance of funding liquidity, coupled with the opportunity to securitize assets, has provided banks with more flexibility in adjusting their balancesheet size. Brunnermeier and Pedersen (2008) emphasize that the extent of liquidity in funding markets can affect the price of risk in financial markets through its effect on the market liquidity of financial assets, and the reduction in margin requirements for traders. The recent financial crisis has demonstrated that the reliance of banks on market-based wholesale funding can create vulnerabilities in the system. Similar to a traditional bank run on retail deposits, a liquidity shortage in wholesale markets can lead to banks losing their short-term funding sources. Unable to roll over their funding, banks would then be forced to dispose of assets and foreclose on loans. This can create systemic effects due to correlated positions of banks, interconnectedness across banks and fire-sale externalities on asset prices (Diamond and Rajan, 2005; De Nicolo et al., 2012; Woodford, 2012).

Excess liquidity in funding markets due to low short-term interest rates and safe-haven flows, coupled with the compensation schemes in financial institutions, has emerged as a key factor in the buildup of risks in the financial system. As Rajan (2006) points out, portfolio managers are typically compensated on the basis of nominal returns. A low interest rate environment, especially if toolow-for-too-long, can thus induce search-for-yield behavior, and lead to higher risk taking in bank and institutional-investor asset portfolios, increasing risks on the asset side of financial institutions. Similarly, a low interest rate environment can lead to a buildup of risks on the liability side of bank balance sheets by steepening the yield curve, which increases the profitability of banks and strengthens banks' capital position. Banks are then further induced to enlarge their balance sheets, financing new assets through short-term borrowing in wholesale funding markets (Adrian and Shin, 2010). The buildup of risks on both the asset and the liability sides of banks' balance sheets during episodes of low interest rates has been dubbed the "risk-taking channel" of monetary policy.

Easy funding and the availability of securitization, along with loosening of lending standards, can lead to a rapid increase in bank lending and asset prices. For example, in the United States, stock market values more than doubled relative to GDP between 1995 and 2000, and house values increased by about 50 per cent relative to GDP between 2000 and 2005. According to the CaseShiller/S\&P index, house prices in major U.S. metropolitan areas increased by about 100 per cent in the same period. The fact that asset prices increased so much and so fast, and so far out of

line from historical norms, has led many to conclude that market participants displayed irrational 
exuberance (see Shiller, 2000). Following the booms, asset prices declined by almost the same order of magnitude, and with equal speed, in these episodes. In particular, stock prices were halved by 2002, only two years after their peak, and house values declined to pre-boom magnitudes by the end of the decade. For many, this served as proof that the booms were caused by exuberance. ${ }^{4}$ Once agents realized that their views on future returns were overly optimistic and would fail to materialize, asset prices quickly reverted back to their previous levels. ${ }^{5}$ These exuberance episodes are arguably less likely to occur without the ample availability of funding liquidity.

\subsection{The case for macroprudential regulations}

In principle, market-determined spreads and market-imposed borrowing constraints on banks and borrowers provide adequate solutions for financial frictions, and markets could deliver second-best social optimum solutions in the absence of regulation. The case for macroprudential policies (such as regulatory bank capital requirements and loan-to-value ratios on mortgages) hinges on the presence of externalities, moral hazard arising from government guarantees, and asset-price exuberance. These prevent market outcomes from reaching the second-best social optimum, and cause banks and borrowers to become overleveraged during booms, thereby increasing the probability of an eventual financial crisis, with severe implications for macroeconomic and financial stability.

As noted earlier, the reliance of banks on uninsured wholesale funds has increased the rollover risk of banks' funding. A liquidity shortage, similar to what was observed in the recent crisis, can have systemic effects due to correlated positions across banks, a fire sale of bank assets and the uncertainty regarding the exposure of financial institutions to banks that are directly affected by the liquidity shortage. Thus, a liquidity shortage initially involving only a handful of financial institutions could quickly develop into a system-wide crisis due to these aforementioned externalities (De Nicolo et al., 2012; Woodford, 2012; Bianchi and Mendoza, 2010). ${ }^{6}$ Note also that moral hazard arising from deposit insurance, and implicit government guarantees based on too-big-to-fail, provides banks with the incentive to enlarge balance sheets and take excessive risks (Kareken and Wallace, 1978; Farhi and Tirole, 2012; Chari and Kehoe, 2009). Similarly, mispricing in complicated and non-transparent financial instuments, such as certain derivatives and asset-backed securities, may lead to incorrect valuations of bank collateral, and result in excessive risk taking by banks (Cociuba et al., 2011). The presence of externalities as discussed above, moral hazard issues based on explicit and implicit guarantees provided by the government, as well as mispricing and exuberance in asset

\footnotetext{
${ }^{4}$ There is a growing literature that studies the role of exuberant expectations and relaxed borrowing constraints on asset prices (see Bernanke and Gertler, 1999; Basant Roi and Mendes, 2007; Garriga et al., 2012; and Granziera and Kozicki, 2012).

${ }^{5}$ Compare this, for example, to the stock market crash of 1973-74, which was as fierce in magnitude and speed; yet it took about two decades for stock values to revert back to pre-crash levels, suggesting that changes in fundamentals, rather than pure exuberance, were the cause of the crash. For more on this stock market episode, see Greenwood and Jovanovic (1999), McGrattan and Prescott (2005), and Alpanda and Peralta-Alva (2010).

${ }^{6}$ Individual agents do not take into account the effects of their actions on asset prices. To the extent that asset prices affect economy-wide spreads and collateral constraints, there are pecuniary externalities arising from asset prices. These externalities lead to overborrowing in booms, and can be internalized via a tax on lending (Bianchi and Mendoza, 2010; Cesa-Bianchi and Rebucci, 2013).
} 
prices, provide a case for macroprudential regulations (Galati and Moessner, 2010; Dell'Ariccia et al., 2012).

In our framework, we allow for shocks that give rise to exuberance in asset prices by influencing the expectations of agents regarding future returns even though these may not be realized. We include pecuniary externalities by allowing spreads to depend on aggregate variables, which borrowers do not internalize when determining how much to borrow. We also capture the implications of moral hazard and asymmetric information by assuming that lenders face monitoring costs when supplying funds to banks, and that banks face monitoring costs when supplying funds to borrowers. We discipline these monitoring costs by allowing them to depend on the leverage positions of banks and borrowers, and calibrate the parameters of our functional form assumptions to roughly match spreads and credit quantities observed in the data.

\section{Model}

The model is a medium-scale small-open-economy DSGE model with real, nominal and financial frictions (see Figure 2 for a brief overview). The model features four types of key agents: patient households (i.e., savers), banks who intermediate between savers and borrowers, and impatient households and entrepreneurs who borrow from banks to help finance their purchases of housing and capital, respectively. On the production side, domestic producers rent capital and labor services to produce the domestic output good, which is aggregated with imported goods to produce five types of final goods: consumption, business investment, residential investment, government expenditure and exports. Importers and exporters are introduced as separate agents in the model to capture the partial pass-through of exchange rate movements to import and export prices at the retail level. The model also features capital and housing producers, as well as monetary, fiscal and macroprudential policy. In what follows, we analyze agents in the model in blocks.

\subsection{Main agents in the model}

\subsubsection{Patient households}

The economy is populated by a unit measure of infinitely lived patient households indexed by $i$, whose intertemporal preferences over consumption, $c_{P, t}$, housing, $h_{P, t}$, and labor supply, $l_{P, t}$, are described by the following expected utility function:

$$
E_{t} \sum_{\tau=t}^{\infty} \beta_{P}^{\tau-t} v_{\tau}\left\{\log \left[c_{P, \tau}(i)-\zeta c_{P, \tau-1}\right]+\xi_{h P} \widetilde{\varepsilon}_{h, \tau} \log h_{P, \tau}(i)-\xi_{l P} \widetilde{\varepsilon}_{l, \tau} \frac{l_{P, \tau}(i)^{1+\vartheta}}{1+\vartheta}\right\}
$$

where $t$ indexes time, $\beta_{P}$ is the time-discount parameter, $\zeta$ is the external habit parameter for consumption, $\vartheta$ is the inverse of the Frisch elasticity of labor supply, and $\xi_{h P}$ and $\xi_{l P}$ are level 
parameters for housing and labor, respectively. The preference shock, $v_{t}$, is an $\operatorname{AR}(1)$ process:

$$
\log v_{t}=\rho_{v} \log v_{t-1}+\varepsilon_{v, t}
$$

where $\rho_{v}$ is the persistence parameter and $\varepsilon_{v, t}$ is an i.i.d. innovation with standard deviation equal to $\sigma_{v}$. The housing demand shock, $\widetilde{\varepsilon}_{h, t}$, and the labor supply shock, $\widetilde{\varepsilon}_{l, t}$, are modelled in a similar fashion.

Labor services are heterogeneous across the patient households, and are aggregated into a homogeneous labor service by perfectly competitive labor intermediaries, who in turn rent these labor services to domestic producers. The labor intermediaries use a standard Dixit-Stiglitz aggregator; therefore, the labor demand curve facing each patient household is given by

$$
l_{P, t}(i)=\left(\frac{W_{P, t}(i)}{W_{P, t}}\right)^{-\eta_{l, t}} l_{P, t},
$$

where $W_{P, t}$ and $l_{P, t}$ are the aggregate nominal wage rate and labor services for patient households, respectively, and $\eta_{l, t}$ is a time-varying elasticity of substitution between the differentiated labor services. To capture cost-push shocks on wages, we specify an exogenous $\operatorname{AR}(1)$ process on $\theta_{w, t}=$ $\eta_{l, t} /\left(\eta_{l, t}-1\right)$ as

$$
\log \theta_{w, t}=\left(1-\rho_{w}\right) \log \theta_{w}+\rho_{w} \log \theta_{w, t-1}+\varepsilon_{w, t},
$$

where $\theta_{w}$ is the gross markup of the real wage over the marginal rate of substitution at the steady state.

The patient households' period budget constraint is given by

$$
\begin{aligned}
c_{P, t}(i)+ & q_{h, t}\left[h_{P, t}(i)-\left(1-\delta_{h}\right) \psi_{h, t} h_{P, t-1}(i)\right] \\
& +q_{k, t}\left[k_{P, t}(i)-\left(1-\delta_{k}\right) \psi_{k, t} k_{P, t-1}(i)\right]+\left(1+\Upsilon_{d, t}\right) \frac{D_{t}(i)}{P_{t}}+\frac{1}{\varkappa_{t}}\left[\frac{B_{t}(i)}{R_{t} P_{t}}+\frac{e_{t} B_{t}^{*}(i)}{\Phi_{t} R_{t}^{*} P_{t}}\right] \\
\leq\left(1-\tau_{l, t}\right) & \frac{W_{P, t}(i)}{P_{t}} l_{P, t}(i)+\left(1-\tau_{k, t}\right) r_{k P, t} \psi_{k, t} k_{P, t-1}(i)+\tau_{k, t} \delta_{k} \psi_{k, t} k_{P, t-1}(i)+R_{d, t-1} \frac{D_{t-1}(i)}{P_{t}} \\
& \quad+\frac{B_{t-1}(i)}{P_{t}}+\frac{e_{t} B_{t-1}^{*}(i)}{P_{t}}+\frac{T R_{P, t}}{P_{t}}+\frac{D_{B, t}}{P_{t}}+\frac{D_{E, t}}{P_{t}}+\frac{\Pi_{d, t}}{P_{t}}+\frac{\Pi_{m, t}}{P_{t}}-\text { adj. costs, }
\end{aligned}
$$

where $P_{t}$ denotes the price level. Patient households use their savings to accumulate physical assets in the form of housing, $h_{P, t}$, and capital, $k_{P, t}$, and financial assets in the form of bank deposits, $D_{t}$, domestic government bonds, $B_{t}$, and foreign government bonds, $B_{t}^{*}$. $q_{h, t}$ and $q_{k, t}$ are the relative prices of housing and capital, respectively, and $\delta_{h}$ and $\delta_{k}$ are their corresponding depreciation rates. $\psi_{h, t}$ and $\psi_{k, t}$ are aggregate housing and capital quality shocks, similar to Gertler and Karadi (2011), and are specified as exogenous $\mathrm{AR}(1)$ processes. These shocks work similar to a change in the physical depreciation rate, by affecting the effective units of assets brought from the previous period; therefore, they capture the economic depreciation or "quality" of these assets. $\Upsilon_{d, t}$ are monitoring costs incurred for the short-term funding of banks, $\Phi_{t}$ is the country risk premium and $\varkappa_{t}$ is a 
portfolio preference term. These features are explained in more detail below.

On the income side, households earn wage income, $W_{P, t}$, and rental income on their capital holdings, $r_{k P, t}$, for which they pay proportional taxes at exogenously determined rates of $\tau_{l, t}$ and $\tau_{k, t}$, respectively (modulo depreciation allowance on capital income tax). They receive interest income from bank deposits at a gross nominal rate of $R_{d, t}$, and from their holdings of domestic and foreign bonds. Households also receive transfers from the government, $T R_{P, t}$, dividends from banks and entrepreneurs, $D_{B, t}$ and $D_{E, t}$, and profits of domestic and import firms, $\Pi_{d, t}$ and $\Pi_{m, t}$, in a lump-sum fashion.

Wage stickiness is introduced via a quadratic cost of wage adjustment similar to Rotemberg (1982),

$$
\frac{\kappa_{w}}{2}\left(\frac{W_{P, t}(i) / W_{P, t-1}(i)}{\pi_{t-1}^{\varsigma w} \pi^{1-\varsigma_{w}}}-1\right)^{2} \frac{\left(\eta_{l, t}-1\right)\left(1-\tau_{l, t}\right) W_{P, t}}{P_{t}} l_{P, t},
$$

where $\kappa_{w}$ is a level parameter, $\pi_{t}=P_{t} / P_{t-1}$ is the aggregate inflation factor and $\varsigma_{w}$ determines the indexation of wage adjustments to past inflation. There are also quadratic costs of adjustment for housing and capital, with level parameters $\kappa_{h P}$ and $\kappa_{k P}$, respectively.

Short-term funding of banks and the bank capital channel In the model, bank deposits are best viewed as wholesale funding (i.e., non-personal deposits and repos), which are not covered by deposit insurance, and are subject to problems that arise from moral hazard and asymmetric information. As such, patient households also play the role of institutional investors in the economy, who trade assets with foreigners and are the source of wholesale funds. ${ }^{7}$

Patient households incur monitoring costs when extending funds to banks, and in return receive full repayment of their lending next period. Although this formulation abstracts from bank default per se, these monitoring costs can be interpreted as the fraction of funds that are defaulted upon by the banks (i.e., "bad loans"), following Curdia and Woodford (2011). Another interpretation of these monitoring costs is that they reflect the cost of purchasing default insurance on funds extended to banks, similar to a credit default swap (Amdur, 2010). These monitoring costs help generate a spread between the funding rate of banks and the risk-free rate (i.e., the funding spread), along the lines of Curdia and Woodford (2011).

We posit that the monitoring costs of investors depend on the leverage position of banks; in particular, banks are able to attract funds at a cheaper rate if they are well-capitalized relative to the capital requirements imposed on their risk-weighted assets:

$$
1+\Upsilon_{d, t}=\chi_{d 1}\left(\frac{\gamma_{t}\left[\omega_{I, t} P_{I, t} b_{I, t}+\omega_{E, t} P_{E, t} b_{E, t}\right]}{A_{t}}\right)^{\chi_{d 2}}\left(\gamma_{t}^{\chi_{d 3}-\chi_{d 2}}\right) \widetilde{\varepsilon}_{d, t}
$$

where $P_{I, t} b_{I, t}$ and $P_{E, t} b_{E, t}$ are the market value of long-term bank loans extended to impatient households and entrepreneurs, respectively, and $A_{t}$ is bank capital in nominal terms. $\gamma_{t}$ is the

\footnotetext{
${ }^{7}$ We could instead separate these two roles by introducing another financial intermediary in between. See, for example, Dib (2010a, 2010b).
} 
capital requirement ratio on banks, while $\omega_{I, t}$ and $\omega_{E, t}$ are the regulatory risk weights applied to household and business loans, respectively. $\chi_{d 1}>1$ is a level parameter determining the funding spread at the steady state, while $\chi_{d 2}$ regulates the elasticity of the funding spread with respect to bank leverage. To preserve the possibility that bank capital regulations could affect funding spreads differently than bank leverage, we let the elasticity of the funding spread to the capital regulation be equal to $\chi_{d 3} . \widetilde{\varepsilon}_{d, t}$ is an $\operatorname{AR}(1)$ shock capturing changes in the riskiness of bank assets not reflected in the regulatory risk weights, perhaps due to a change in the market perception of their collateral value or the assets' market liquidity.

An advantage of our approach of modelling financial frictions through monitoring costs (that depend on the leverage of banks and the capital requirement they face) is that the capital requirement on banks does not have to bind every period to solve the model. Indeed, should bank leverage deviate from the regulatory ratio, $1 / \gamma_{t}$, in a particular period, the funding spread faced by the bank would endogenously adjust. Hence, in our approach, the quantity constraint imposed by the capital requirement on banks translates into endogenous changes in spreads. This is a flexible and tractable alternative to the computationally more demanding problem of solving the model with occasionally binding capital requirement constraints.

Country risk premium Domestic and foreign bonds trade at a discount $R_{t}$ and $\Phi_{t} R_{t}^{*}$, respectively, where $R_{t}$ and $R_{t}^{*}$ are the policy rates in the domestic and foreign economies, while $\Phi_{t}$ is the country risk premium. The specification for the country risk premium is

$$
\Phi_{t}=\exp \left[-\Phi_{a}\left(n f a_{t}-\overline{n f a}\right)-\Phi_{e}\left(\frac{E_{t} e_{t+1}}{e_{t}} \frac{e_{t}}{e_{t-1}}-1\right)+\widetilde{\Phi}_{t}\right]
$$

where $n f a_{t}=e_{t} B_{t}^{*} / \varkappa_{t} \Phi_{t} R_{t}^{*} P_{t} y_{d, t}$ is the net foreign asset position, and $e_{t}$ is the nominal exchange rate quoted in terms of Canadian dollars per unit of foreign currency. The first term in the specification captures the negative relationship between a country's risk premium and its net foreign asset position, with $\Phi_{a}$ being an elasticity parameter. This debt-elastic country risk specification follows Schmitt-Grohe and Uribe (2003), and is necessary to ensure that the stochastic discount factor of patient households is stationary. The second component of the country risk premium depends on the current and the expected depreciation rates, with $\Phi_{e}$ determining the relevant elasticity. This specification is due to Adolfson et al. (2008), and allows for a negative relationship between the country risk premium and the expected depreciation rate, which can account for the forward premium puzzle observed in the data. The third component of the country risk premium, $\widetilde{\Phi}_{t}$, is exogenous and follows an $\operatorname{AR}(1)$ process.

Portfolio preference and the risk-taking channel The discounting for the risk-free asset returns is additionally impacted by the term, $\varkappa_{t}$, which is modelled as a time-varying "tax wedge" on risk-free bond returns (Smets and Wouters, 2007; Chari et al., 2007; Amano and Shukayev, 2012; Alpanda, 2013). An increase in $\varkappa_{t}$ induces patient households to rebalance their asset portfolios away 
from "risky" assets such as bank deposits and capital, and toward "safe" assets such as domestic and foreign bonds (i.e., "flight-to-quality"). Similarly, a decrease in $\varkappa_{t}$ results in agents switching their portfolios toward riskier assets (i.e., "search-for-yield"). As such, $\varkappa_{t}$ captures changes in the risk appetite of investors and induces the related portfolio adjustments.

As argued in the introduction, during economic upturns, the market price of risk in financial markets is reduced and the overall attitudes of investors and financial intermediaries become more favorable to taking on more risk (Brunnermeier and Pedersen, 2008; Adrian and Shin, 2010). To capture this element of the risk-taking channel, we let part of the portfolio preference term, $\varkappa_{t}$, be endogenously determined based on the overall conditions in real activity. In particular, we let

$$
\varkappa_{t}=\left(\frac{y_{t}}{y}\right)^{-\varrho_{\varkappa}} \widetilde{\varepsilon}_{\varkappa, t},
$$

where $y_{t}$ and $y$ are aggregate output and its steady-state value, respectively, $\varrho_{\varkappa}$ is an elasticity parameter, and $\widetilde{\varepsilon}_{\varkappa, t}$ is an exogenous $\operatorname{AR}(1)$ process.

This feature, when $\varrho_{\varkappa}>0$, adds an additional amplification mechanism into the model, where a favorable shock that leads to an increase in economic activity is further reinforced by the increase in the risk appetite of investors. This leads to an increase in asset prices above and beyond what would be observed in the absence of this feature. Banks are then able to fund themselves at cheaper rates, which allows them to enlarge their balance-sheet size, while monitoring costs and risk premia are also reduced due to the effects of asset prices on the net worth position of borrowers.

Optimality conditions The patient households' objective is to maximize utility subject to the budget constraint, the labor demand curve of labor intermediaries and appropriate No-Ponzi conditions. The first-order condition with respect to consumption equates the marginal utility gain from consumption to the marginal cost of spending a unit out of the budget (i.e., $\lambda_{P, t}$, the Lagrange multiplier on the budget constraint).

The optimality condition for housing equates the marginal cost of acquiring a unit of housing to the marginal utility gain from housing services and the discounted value of expected capital gains, which (ignoring adjustment costs) can be written as

$$
q_{h, t}=\xi_{h P} \widetilde{\varepsilon}_{h, t} \frac{c_{P, t}-\zeta c_{P, t-1}}{h_{P, t}}+E_{t}\left[\left(\beta_{P} \frac{\lambda_{P, t+1}}{\lambda_{P, t}}\right)\left(1-\delta_{h}\right) \psi_{h, t+1} \varkappa_{h, t} q_{h, t+1}\right] .
$$

Note that the expected capital gains has an additional term, $\varkappa_{h, t}$, capturing pure exuberance, which drives a wedge between the observed asset price and its "fundamental value," similar to Bernanke and Gertler (1999) and Basant Roi and Mendes (2007). Unlike the housing quality shock, $\psi_{h, t}$, which is expected ex ante and realized ex post, the housing exuberance shock is expected ex ante but not realized afterwards. Therefore, it can be considered an unrealized news shock on future housing quality, as in Gertler and Karadi (2011).

Similarly, the optimality condition for capital equates the marginal cost of acquiring a unit of 
capital to the expected marginal gains from rents and capital gains, which (ignoring adjustment costs) can be written as

$$
q_{k, t}=E_{t}\left[\left(\beta_{P} \frac{\lambda_{P, t+1}}{\lambda_{P, t}}\right)\left[\left(1-\delta_{k}\right) q_{k, t+1}+\left(1-\tau_{k, t}\right) r_{k P, t+1}+\tau_{k, t} \delta_{k}\right] \psi_{k, t+1} \varkappa_{k, t}\right],
$$

where $\varkappa_{k, t}$ is an exuberance shock for expected capital returns, similar to the one on housing. The exuberance shocks for housing and capital returns are specified as exogenous AR(1) processes.

Arbitrage between domestic bonds and bank deposits implies (after log-linearization):

$$
\widehat{R}_{d, t}-\widehat{R}_{t}=\widehat{\Upsilon}_{d, t}+\widehat{\varkappa}_{t}
$$

which relates the funding spread faced by banks to banks' leverage ratio and the risk appetite of savers. Arbitrage between domestic and foreign bonds implies the UIP condition (after loglinearization):

$$
\widehat{e}_{t}=\left(1-\Phi_{e}\right) E_{t} \widehat{e}_{t+1}+\Phi_{e} E_{t} \widehat{e}_{t-1}-\left(\widehat{R}_{t}-\widehat{R}_{t}^{*}\right)-\Phi_{a}\left(n f a_{t}-\overline{n f a}\right)+\widetilde{\Phi}_{t}
$$

The optimality conditions with respect to labor and wages can be combined to derive a New Keynesian wage Phillips curve (after log-linearization):

$$
\widehat{\pi}_{w P, t}-\varsigma_{w} \widehat{\pi}_{t-1}=\beta_{P} E_{t}\left[\widehat{\pi}_{w P, t+1}-\varsigma_{w} \widehat{\pi}_{t}\right]-\frac{1}{\kappa_{w}}\left[\widehat{w}_{P, t}-\left(\vartheta \widehat{l}_{P, t}+\frac{1}{1-\zeta}\left(\widehat{c}_{P, t}-\zeta \widehat{c}_{P, t-1}\right)\right)-\widehat{\theta}_{w, t}\right],
$$

where the nominal wage inflation, $\widehat{\pi}_{w P, t}$, and the real wage rate, $\widehat{w}_{P, t}$, for patient households are related as

$$
\widehat{\pi}_{w P, t}-\widehat{\pi}_{t}=\widehat{w}_{P, t}-\widehat{w}_{P, t-1} .
$$

Since households are wage setters in the labor market, wages are marked up relative to the marginal rate of substitution (MRS) between leisure and consumption. Wage stickiness, along with exogenous markup shocks, provides variation in the wedge between wages and MRS with a long-run correction to the steady-state markup.

\subsubsection{Banks}

There is a unit measure of banks indexed by $i$, which use deposits and their own capital to fund their lending to impatient households and entrepreneurs. Bank loans are modelled as perpetuities with exponentially decaying coupon payments, as in Woodford (2001). In particular, each unit of bank loan $z \in\{I, E\}$ is valued at $P_{z, t}$ dollars in period $t$, and gives the bank the right to payments of $P_{t} \delta_{z}^{t+s}$ at period $t+s+1$ for all $s \geq 0$. In other words, in return for a unit of loan, a bank is entitled to receive $P_{t}$ in period $t+1, P_{t} \delta_{I}$ in period $t+2, P_{t} \delta_{I}^{2}$ in period $t+3$, etc., for household loans, and similar coupon payments for entrepreneurial loans. 
Note that a long-term bank loan extended last period would pay coupon payments of $P_{t-1} \delta_{z}^{t+s+1}$ at period $t+s+1$ for $s \geq 0$; hence, this loan would be priced in period $t$ as $\delta_{z} P_{z, t} / \pi_{t}$. This allows us to write the banks' cash flow in recursive form as

$$
\begin{aligned}
\frac{D_{B, t}}{P_{t}}+ & R_{d, t-1} \frac{D_{t-1}}{P_{t}}+\left(1+\Upsilon_{I, t}\right) \frac{P_{I, t}}{P_{t}} b_{I, t}+\left(1+\Upsilon_{E, t}\right) \frac{P_{E, t}}{P_{t}} b_{E, t} \\
& \leq \frac{\left(P_{t-1}+\delta_{I} P_{I, t} / \pi_{t}\right)}{P_{t}} b_{I, t-1}+\frac{\left(P_{t-1}+\delta_{E} P_{E, t} / \pi_{t}\right)}{P_{t}} b_{E, t-1}+\frac{D_{t}}{P_{t}}-\text { adj. costs }
\end{aligned}
$$

where $D_{B, t}$ are dividends paid out to shareholders, $P_{I, t} b_{I, t}$ and $P_{E, t} b_{E, t}$ denote the nominal market value of the stock of long-term loans extended to impatient households and entrepreneurs, respectively, and $\Upsilon_{I, t}$ and $\Upsilon_{E, t}$ denote monitoring costs incurred by banks when extending household and business loans (explained in more detail below). Banks also incur quadratic costs of adjustment for changing dividends, with level parameter $\kappa_{d B}$; this feature is similar to Jermann and Quadrini (2012), and captures evidence in the corporate finance literature regarding the smoothing of corporate dividend payouts. It also ensures that banks cannot decrease dividends too much during recessions, and therefore the decline in their net worth cannot be fully cushioned by a corresponding decline in dividend payments.

The balance-sheet position of bank $i$ at the end-of-period $t$ is given by

$$
\frac{P_{I, t}}{P_{t}} b_{I, t}(i)+\frac{P_{E, t}}{P_{t}} b_{E, t}(i)=\frac{D_{t}(i)}{P_{t}}+\frac{A_{t}(i)}{P_{t}},
$$

where $A_{t}$ denotes the net worth of the bank (i.e., bank capital). Letting $p_{z, t}=P_{z, t} / P_{t}$, and defining the gross yield on bank asset $z$ as

$$
R_{z, t}=\frac{1}{p_{z, t}}+\delta_{z}
$$

we can write the bank's cash-flow condition as

$$
\begin{aligned}
& \frac{D_{B, t}(i)}{P_{t}}+R_{d, t-1} \frac{D_{t-1}(i)}{P_{t}}+\left(1+\Upsilon_{I, t}\right) p_{I, t} b_{I, t}(i)+\left(1+\Upsilon_{E, t}\right) p_{E, t} b_{E, t}(i) \\
& \quad \leq \frac{R_{I, t}}{\pi_{t}} p_{I, t} b_{I, t-1}(i)+\frac{R_{E, t}}{\pi_{t}} p_{E, t} b_{E, t-1}(i)+\frac{D_{t}(i)}{P_{t}}-\text { adj. costs. }
\end{aligned}
$$

\section{Monitoring costs of banks, the balance-sheet channel and the adverse feedback loop} Banks incur monitoring costs when extending household and business loans. Similar to the funding spread, the monitoring costs help generate credit spreads between the lending rates of banks and their funding rate, as in Curdia and Woodford (2011). The monitoring costs of banks depend on the leverage position of borrowers; in particular, borrowers can get loans at cheaper rates if they 
have a larger equity stake in the asset purchased relative to the equity required by regulations:

$$
\begin{aligned}
1+\Upsilon_{I, t} & =\chi_{I 1}\left(\frac{\left(1-m_{I, t}\right) q_{h, t} h_{I, t}}{n_{I, t}}\right)^{\chi_{I 2}} \widetilde{\varepsilon}_{I, t}, \\
1+\Upsilon_{E, t} & =\chi_{E 1}\left(\frac{\left(1-m_{E}\right) q_{k, t} k_{E, t}}{n_{E, t}}\right)^{\chi_{E 2}} \widetilde{\varepsilon}_{E, t},
\end{aligned}
$$

where $h_{I, t}$ and $k_{E, t}$ denote housing and capital purchased by impatient households and entrepreneurs, respectively. Similarly, $n_{I, t}$ and $n_{E, t}$ denote the real net worth of impatient households and entrepreneurs, respectively, and are given by

$$
\begin{aligned}
n_{I, t} & =q_{h, t} h_{I, t}-p_{I, t} b_{I, t}, \\
n_{E, t} & =q_{k, t} k_{E, t}-p_{E, t} b_{E, t} .
\end{aligned}
$$

$m_{I, t}$ is the regulatory loan-to-value (LTV) ratio on mortgage loans, whereas $m_{E}$ denotes the debtto-asset ratio of entrepreneurs at the steady state. $\chi_{I 1}$ and $\chi_{E 1}$ are level parameters, while $\chi_{I 2}$ and $\chi_{E 2}$ regulate the elasticity of monitoring costs with respect to borrower leverage. $\widetilde{\varepsilon}_{I, t}$ and $\widetilde{\varepsilon}_{E, t}$ are exogenous shocks to monitoring costs, which follow $\mathrm{AR}(1)$ processes. These shocks reflect changes in the perceived riskiness of loans not captured by borrower leverage, similar to shocks to collateral quality in Boivin et al. (2010), and shocks to the variance of entrepreneurs' project returns in Christiano et al. (2010).

Note that the model features an adverse feedback loop similar to Davis (2010). In particular, adverse shocks that increase the monitoring costs of banks, $\Upsilon_{I, t}$ and $\Upsilon_{E, t}$, also reduce the level of bank capital directly, since these costs reduce the amount of retained earnings that could be added to bank capital. The increase in lending rates also reduces the price of bank assets, since

$$
p_{z, t}=\frac{1}{R_{z, t}-\delta_{z}}
$$

This leads to a further deterioration in banks' capital position, raising banks' funding costs, and adversely affecting bank lending.

Optimality conditions The objective of banks is to maximize the present value of dividend payouts:

$$
\max E_{t} \sum_{\tau=t}^{\infty} \beta_{B}^{\tau-t} \frac{\lambda_{P, \tau}}{\lambda_{P, t}}\left[v_{B, \tau} \frac{D_{B, \tau}(i)}{P_{\tau}}\right],
$$

where they discount future flows using the stochastic discount factor of shareholders (i.e., patient households), except that their time-discount factor, $\beta_{B}$, is slightly lower than that of patient households, to ensure non-negative flows from patient households to banks at the steady state (Iacoviello, 2013). $v_{B, t}$ is an exogenous $\mathrm{AR}(1)$ process capturing banks' preference changes with respect to 
paying dividends versus retaining earnings. ${ }^{8}$

The first-order condition with respect to dividends yields

$$
\left(\frac{d_{B, t}}{d_{B, t-1}}-1\right) \frac{d_{B, t}}{d_{B, t-1}}=E_{t}\left\{\left(\beta_{B} \frac{\lambda_{P, t+1}}{\lambda_{P, t}} \frac{\lambda_{B, t+1}}{\lambda_{B, t}}\right)\left[\left(\frac{d_{B, t+1}}{d_{B, t}}-1\right)\left(\frac{d_{B, t+1}}{d_{B, t}}\right)^{2}\right]\right\}-\frac{1}{\kappa_{d B}}\left(1-\frac{v_{B, t}}{\lambda_{B, t}}\right)
$$

where $d_{B, t}$ are real dividends, and $\lambda_{B, t}$ is the Lagrange multiplier on the cash-flow condition (which is equal to 1 at the steady state or when dividend adjustment costs are 0). Banks choose to attract deposits up to the point where they equate the marginal gain to the expected discounted funding cost, which is given by

$$
1=E_{t}\left[\left(\beta_{B} \frac{\lambda_{P, t+1}}{\lambda_{P, t}} \frac{\lambda_{B, t+1}}{\lambda_{B, t}}\right) \frac{R_{d, t}}{\pi_{t+1}}\right] .
$$

The optimality conditions for household and business loans similarly equate the marginal cost of increasing lending with the expected discounted return on these loans:

$$
\begin{gathered}
\left(1+\Upsilon_{I, t}\right) p_{I, t}=E_{t}\left[\left(\beta_{B} \frac{\lambda_{P, t+1}}{\lambda_{P, t}} \frac{\lambda_{B, t+1}}{\lambda_{B, t}}\right) \frac{R_{I, t+1} p_{I, t+1}}{\pi_{t+1}}\right], \\
\left(1+\Upsilon_{E, t}\right) p_{E, t}=E_{t}\left[\left(\beta_{B} \frac{\lambda_{P, t+1}}{\lambda_{P, t}} \frac{\lambda_{B, t+1}}{\lambda_{B, t}}\right) \frac{R_{E, t+1} p_{E, t+1}}{\pi_{t+1}}\right] .
\end{gathered}
$$

Log-linearizing these expressions, and combining them with (27) and (24), we get

$$
\widehat{R}_{z, t}=\left(1-\frac{\delta_{z}}{R_{z}}\right) \sum_{s=0}^{\infty}\left(\frac{\delta_{z}}{R_{z}}\right)^{s} E_{t}\left[\widehat{R}_{d, t+s}+\widehat{\Upsilon}_{z, t+1}\right], \text { for } z \in\{I, E\}
$$

which implies that the banks' lending rate depends not only on current, but also on expected future deposit rates and monitoring costs. We can further combine this with (12) to get

$$
\widehat{R}_{z, t}=\left(1-\frac{\delta_{z}}{R_{z}}\right) \sum_{s=0}^{\infty}\left(\frac{\delta_{z}}{R_{z}}\right)^{s} E_{t}\left[\widehat{R}_{t+s}+\widehat{\varkappa}_{t+s}+\widehat{\Upsilon}_{d, t+s}+\widehat{\Upsilon}_{z, t+1}\right], \text { for } z \in\{I, E\}
$$

which implies that long-term rates faced by borrowers depend on (i) the interest rate on long-term government bonds (based on the expectations hypothesis), (ii) the bank funding spread based on current and future bank leverage and investor appetite, and (iii) the bank lending spread based on current and future borrower leverage.

\subsubsection{Impatient households}

The economy is also populated by a unit measure of infinitely lived impatient households. Their utility function is identical to that of patient households, except that their time-discount factor is

\footnotetext{
${ }^{8}$ In principle, we can have negative dividends, which would capture new equity injections from shareholders; see Jermann and Quadrini (2012) and Alpanda (2013).
} 
assumed to be less than banks to facilitate borrowing; hence, $\beta_{I}<\beta_{B}$. Labor services of impatient households are also heterogeneous, and are aggregated into a homogeneous labor service by perfectly competitive labor intermediaries using a Dixit-Stiglitz aggregator. The labor demand curve facing each impatient household is thus given by

$$
l_{I, t}(i)=\left(\frac{W_{I, t}(i)}{W_{I, t}}\right)^{-\eta_{l, t}} l_{I, t}
$$

where $W_{I, t}$ and $l_{I, t}$ are the aggregate nominal wage rate and labor services for impatient households, respectively.

The impatient households' period budget constraint is given by

$$
\begin{aligned}
c_{I, t}(i)+ & q_{h, t}\left[h_{I, t}(i)-\left(1-\delta_{h}\right) \psi_{h, t} h_{I, t-1}(i)\right]+\frac{R_{I, t}}{\pi_{t}} p_{I, t} b_{I, t-1}(i) \\
\leq & \left(1-\tau_{l, t}\right) \frac{W_{I, t}(i)}{P_{t}} l_{I, t}(i)+p_{I, t} b_{I, t}(i)+\frac{T R_{I, t}}{P_{t}}-\operatorname{adj} . \text { costs },
\end{aligned}
$$

where $T R_{I, t}$ denotes lump-sum transfers received from the government. Impatient households also face quadratic adjustment costs in the change in wage rates with level parameter $\kappa_{w}$.

The first-order conditions of the impatient households with respect to consumption, housing and wages are similar to those of patient households. The optimality condition for their borrowing is given by

$$
p_{I, t}=E_{t}\left[\left(\beta_{I} \frac{\lambda_{I, t+1}}{\lambda_{I, t}}\right) \frac{R_{I, t+1} p_{I, t+1}}{\pi_{t+1}}\right],
$$

which equates the marginal gain of borrowing to the expected discounted interest cost.

\subsubsection{Entrepreneurs}

There is a unit measure of entrepreneurs in the economy indexed by $i$. Entrepreneurs purchase capital from capital producers, financing this purchase through bank loans and retained earnings. Entrepreneur $i$ 's cash-flow condition at period $t$ is given by

$$
\begin{aligned}
\frac{D_{E, t}(i)}{P_{t}} & +q_{k, t}\left[k_{E, t}(i)-\left(1-\delta_{k}\right) \psi_{k, t} k_{E, t-1}(i)\right]+\frac{R_{E, t}}{\pi_{t}} p_{E, t} b_{E, t-1}(i) \\
\leq & \left(1-\tau_{k, t}\right) r_{k E, t} \psi_{k, t} k_{E, t-1}(i)+\tau_{k, t} \delta_{k} \psi_{k, t} k_{E, t-1}(i)+p_{E, t} b_{E, t}(i)-\text { adj. costs, }
\end{aligned}
$$

where $k_{E, t}$ denotes entrepreneurial capital, and $D_{E, t}$ denotes dividends paid out to shareholders. Entrepreneurs also face quadratic adjustment costs in the change in dividends with level parameter $\kappa_{d E}$.

The objective of the entrepreneur is to maximize the present value of dividend payouts:

$$
\max E_{t} \sum_{\tau=t}^{\infty} \beta_{E}^{\tau-t} \frac{\lambda_{P, \tau}}{\lambda_{P, t}}\left[v_{E, \tau} \frac{D_{E, \tau}(i)}{P_{\tau}}\right],
$$


where they discount future flows using the stochastic discount factor of shareholders (i.e., patient households), except that their time-discount factor is slightly lower (i.e., $\beta_{E}<\beta_{B}$ ), to ensure nonnegative flows from banks to entrepreneurs at the steady state (Iacoviello, 2013). $v_{E, t}$ is an exogenous $\mathrm{AR}(1)$ process capturing entrepreneurs' preference changes with respect to paying dividends versus retaining earnings. The first-order condition with respect to dividends yields

$$
\left(\frac{d_{E, t}}{d_{E, t-1}}-1\right) \frac{d_{E, t}}{d_{E, t-1}}=E_{t}\left\{\left(\beta_{E} \frac{\lambda_{P, t+1}}{\lambda_{P, t}} \frac{\lambda_{E, t+1}}{\lambda_{E, t}}\right)\left[\left(\frac{d_{E, t+1}}{d_{E, t}}-1\right)\left(\frac{d_{E, t+1}}{d_{E, t}}\right)^{2}\right]\right\}-\frac{1}{\kappa_{d E}}\left(1-\frac{v_{E, t}}{\lambda_{E, t}}\right),
$$

where $d_{E, t}$ is real dividends, and $\lambda_{E, t}$ is the Lagrange multiplier on the cash-flow condition.

The optimality condition with respect to capital (ignoring adjustment costs) equates the marginal cost of purchasing capital with the expected discounted marginal capital gains and rental returns:

$$
q_{k, t}=E_{t}\left[\left(\beta_{E} \frac{\lambda_{P, t+1}}{\lambda_{P, t}} \frac{\lambda_{E, t+1}}{\lambda_{E, t}}\right)\left[\left(1-\delta_{k}\right) q_{k, t+1}+\left(1-\tau_{k, t}\right) r_{k E, t+1}+\tau_{k, t} \delta_{k}\right] \psi_{k, t+1} \varkappa_{k, t}\right] .
$$

Entrepreneurs borrow up to the point where they equate the marginal gain from receiving a unit of loan to the expected discounted interest costs:

$$
p_{E, t}=E_{t}\left[\left(\beta_{E} \frac{\lambda_{P, t+1}}{\lambda_{P, t}} \frac{\lambda_{E, t+1}}{\lambda_{E, t}}\right) \frac{R_{E, t+1} p_{E, t+1}}{\pi_{t+1}}\right] .
$$

The two conditions above imply that, at the optimum, the demand for entrepreneurial capital increases up to the point where the expected return from capital is equated to the cost of borrowing from banks.

\subsection{Goods production}

\subsubsection{Final-goods aggregators}

There are five different types of final-goods aggregators: for consumption goods, $c_{t}$, capital investment goods, $i_{k, t}$, housing investment goods, $i_{h, t}$, government expenditure goods, $g_{t}$, and export goods, $y_{x, t}$. In what follows, we describe the consumption-goods aggregators, but the others are modelled in an analogous fashion.

Non-residential consumption final-goods producers are perfectly competitive, and they produce consumption final goods, $c_{t}$, using domestic goods, $c_{d, t}$, and imported goods, $c_{m, t}$, as inputs:

$$
c_{t}=\left[\left(1-\phi_{c} \phi_{t}\right)^{\frac{1}{\eta_{c}}}\left(c_{d, t}\right)^{\frac{\eta_{c}-1}{\eta_{c}}}+\left(\phi_{c} \phi_{t}\right)^{\frac{1}{\eta_{c}}}\left(c_{m, t}\right)^{\frac{\eta_{c}-1}{\eta_{c}}}\right]^{\frac{\eta_{c}}{\eta_{c}-1}}
$$

where $\phi_{c}$ denotes the share of imports in the consumption-goods aggregator, and $\eta_{c}$ is the elasticity of substitution between domestic and imported goods. To capture shocks to import demand, the share of imports for consumption final goods is assumed to be subject to exogenous variation following an 
$\mathrm{AR}(1)$ process:

$$
\log \phi_{t}=\rho_{\phi} \log \phi_{t-1}+\varepsilon_{\phi, t}
$$

Since the final-goods producers are perfectly competitive, they earn zero profits in equilibrium. For any level of output, their optimal demand for the domestic and imported goods is thus given by

$$
\begin{aligned}
c_{d, t} & =\left(\frac{P_{d, t}}{P_{t}}\right)^{-\eta_{c}}\left(1-\phi_{c} \phi_{t}\right) c_{t}, \\
c_{m, t} & =\left(\frac{P_{m, t}}{P_{t}}\right)^{-\eta_{c}} \phi_{c} \phi_{t} c_{t},
\end{aligned}
$$

where $P_{d, t}$ and $P_{m, t}$ are the prices of the domestic and imported goods, respectively, while $P_{t}$ is the price of the final consumption good. Note that, in equilibrium, the final consumption-goods production is equal to purchases by patient and impatient households:

$$
c_{t}=c_{P, t}+c_{I, t}
$$

\subsubsection{Domestic firms}

There is a unit measure of monopolistically competitive domestic firms indexed by $j$. Their technology is described by the following production function:

$$
y_{d, t}(j)=z_{t}\left\{\left[u_{P, t}(j) k_{P, t-1}(j)\right]^{\mu_{k}}\left[u_{E, t}(j) k_{E, t-1}(j)\right]^{1-\mu_{k}}\right\}^{\alpha}\left[l_{P, t}(j)^{\mu_{l}} l_{I, t}(j)^{1-\mu_{l}}\right]^{1-\alpha}-f_{d}
$$

where $\alpha$ is the share of capital in overall production, and $\mu_{k}$ and $\mu_{l}$ denote the shares of patient households in capital and labor inputs. $u_{P, t}$ and $u_{E, t}$ denote the utilization rates for each type of capital, and $f_{d}$ is a fixed cost of production. ${ }^{9}$ The aggregate productivity shock, $z_{t}$, follows an $\operatorname{AR}(1)$ process.

Domestic goods produced are heterogeneous across firms, and are aggregated into a homogeneous domestic good by perfectly competitive final-goods producers using a standard Dixit-Stiglitz aggregator. The demand curve facing each firm is given by

$$
y_{d, t}(j)=\left(\frac{P_{d, t}(j)}{P_{d, t}}\right)^{-\eta_{d, t}} y_{d, t}
$$

where $y_{d, t}$ is aggregate domestic output, and $\eta_{d, t}$ is a time-varying elasticity of substitution between the differentiated goods. To capture cost-push shocks, we specify an exogenous AR(1) process on $\theta_{d, t}=\eta_{d, t} /\left(\eta_{d, t}-1\right)$,

$$
\log \theta_{d, t}=\left(1-\rho_{d}\right) \log \theta_{d}+\rho_{d} \log \theta_{d, t-1}+\varepsilon_{d, t},
$$

where $\theta_{d}$ is the gross markup of price over marginal cost at the steady state.

\footnotetext{
${ }^{9}$ The fixed-cost parameter $f_{d}$ is set equal to $\theta_{d}-1$ times the steady-state level of output to ensure that pure economic profits are zero at the steady state; hence, there is no incentive for firm entry and exit in the long run.
} 
Firm $j$ 's profits at period $t$ are given by

$$
\begin{aligned}
\frac{\Pi_{d, t}(j)}{P_{t}} & =\frac{P_{d, t}(j)}{P_{t}} y_{d, t}(j)-\frac{W_{P, t}}{P_{t}} l_{P, t}(j)-\frac{W_{I, t}}{P_{t}} l_{I, t}(j)-r_{k P, t} \psi_{k, t} k_{P, t-1}(j)-r_{k E, t} \psi_{k, t} k_{E, t-1}(j) \\
& -\frac{\kappa_{u P}}{1+\varpi}\left[u_{P t}(j)^{1+\varpi}-1\right] k_{P, t-1}(j)-\frac{\kappa_{u E}}{1+\varpi}\left[u_{E, t}(j)^{1+\varpi}-1\right] k_{E, t-1}(j)-\text { adj. costs, }
\end{aligned}
$$

where $\kappa_{u P}$ and $\kappa_{u E}$ are level parameters, and $\varpi$ is the elasticity parameter for the utilization cost specification. Similar to wage stickiness, price stickiness is introduced via quadratic adjustment costs with level parameter $\kappa_{d}$, and $\varsigma_{d}$ captures the extent to which price adjustments are indexed to past inflation.

A domestic firm's objective is to choose the quantity of inputs and output, and the price of its output each period, to maximize the present value of profits (using the patient households' stochastic discount factor), subject to the demand function they are facing with respect to their individual output from the aggregators. At the optimum, the relative demand for the two types of labor is related to relative wage rates as

$$
\frac{l_{I, t}}{l_{P, t}}=\left(\frac{1-\mu_{l}}{\mu_{l}}\right) \frac{w_{P, t}}{w_{I, t}}
$$

where $w_{P, t}$ and $w_{I, t}$ are real wages deflated by the composite goods price, $P_{t}$. Similarly, the relative demand for the two types of capital is related to the relative rental rates of capital as

$$
\frac{k_{E, t-1}}{k_{P, t-1}}=\left(\frac{1-\mu_{k}}{\mu_{k}}\right) \frac{r_{k P, t}+\frac{\kappa_{u P}}{1+\varpi}\left(u_{P, t}^{1+\varpi}-1\right)}{r_{k E, t}+\frac{\kappa_{u E}}{1+\varpi}\left(u_{E, t}^{1+\varpi}-1\right)} .
$$

The optimality condition for capital utilization similarly equates the marginal cost of increasing utilization at the margin with the revenue gain that arises from increased production.

The first-order condition for prices yields (after log-linearization) the following New Keynesian Phillips curve for domestic-goods inflation:

$$
\widehat{\pi}_{d, t}=\frac{\beta_{P}}{1+\beta_{P} \varsigma_{d}} E_{t} \widehat{\pi}_{d, t+1}+\frac{\varsigma_{d}}{1+\beta_{P} \varsigma_{d}} \widehat{\pi}_{d, t-1}+\frac{1}{\left(1+\beta_{P} \varsigma_{d}\right) \kappa_{d}}\left(\widehat{w}_{P, t}+\widehat{l}_{P, t}-\widehat{p}_{d, t}-\frac{1}{\theta_{d}} \widehat{y}_{d, t}+\widehat{\theta}_{d, t}\right) .
$$

Due to market power, domestic producers set the price of their goods at a markup relative to marginal cost. The adjustment costs in price setting, as well as exogenous markup shocks, introduce variation in these markups with a long-run adjustment to the steady-state markup. The nominal rigidities in price setting imply that shocks that alter the marginal cost of production feed into domestic-goods inflation slowly. 


\subsection{International trade}

\subsubsection{Importers}

There is a unit measure of monopolistically competitive importers indexed by $i$. They import foreign goods from abroad, differentiate them and mark up their price, and then sell these heterogeneous goods to perfectly competitive import aggregators, who aggregate them into a homogeneous import good using a standard Dixit-Stiglitz aggregator. The demand curve facing each importer is given by

$$
y_{m, t}(j)=\left(\frac{P_{m, t}(j)}{P_{m, t}}\right)^{-\eta_{m, t}} y_{m, t},
$$

where $y_{m, t}$ is aggregate imports, and $\eta_{m, t}$ is a time-varying elasticity of substitution between the differentiated goods. To capture cost-push shocks, we specify an exogenous $\mathrm{AR}(1)$ process on $\theta_{m, t}=$ $\eta_{m, t} /\left(\eta_{m, t}-1\right)$

$$
\log \theta_{m, t}=\left(1-\rho_{\theta m}\right) \log \theta_{m}+\rho_{\theta m} \log \theta_{m, t-1}+\varepsilon_{\theta m, t},
$$

where $\theta_{m}$ is the gross markup of the domestic price of imported goods over its import price at the steady state.

Importers maximize the present value of profits (using the patient households' stochastic discount factor) subject to the demand function they are facing from the aggregators with respect to their own output. The importer's profits at period $t$ are given by

$$
\frac{\Pi_{m, t}(j)}{P_{t}}=\frac{P_{m, t}(j)}{P_{t}} y_{m, t}(j)-\frac{e_{t} P_{t}^{*}}{P_{t}} y_{m, t}(j)-\text { adj. cost }
$$

where importers face quadratic price adjustment costs, which helps generate partial exchange rate pass-through to domestic prices. $\kappa_{m}$ and $\varsigma_{m}$ are the price adjustment cost and indexation parameters, respectively.

The first-order conditions of importers yield the following New Keynesian Phillips curve for import prices (after log-linearization): ${ }^{10}$

$$
\widehat{\pi}_{m, t}=\frac{\beta_{P}}{1+\beta_{P \varsigma_{m}}} E_{t} \widehat{\pi}_{m, t+1}+\frac{\varsigma_{m}}{1+\beta_{P \varsigma_{m}}} \widehat{\pi}_{m, t-1}-\frac{1}{\left(1+\beta_{P} \varsigma_{m}\right) \kappa_{m}}\left(\widehat{p}_{m, t}-\widehat{r e r}_{t}-\widehat{\theta}_{m, t}\right),
$$

where $\operatorname{rer}_{t}=e_{t} P_{t}^{*} / P_{t}$ is the real exchange rate. Due to market power, importers set the price of imported goods at a markup relative to the price at which they imported the goods. The adjustment costs in price setting, as well as exogenous markup shocks, introduce variation in these markups with a long-run adjustment to the steady-state markup. The nominal rigidities in the domestic price of imports also introduce partial exchange rate pass-through; variations in the nominal exchange rate alter the costs of importers, but these are not reflected fully on domestic import-goods prices immediately.

\footnotetext{
${ }^{10} \mathrm{We}$ assume the existence of subsidies that correct the inefficiencies created by price markups on importers and exporters. This allows us to set relative prices equal to 1 at the steady state.
} 


\subsubsection{Exporters}

Export firms are modelled analogous to importers, but are located in foreign countries. They purchase the domestic goods for $P_{t}$ in Canadian dollars, but sell them abroad for $P_{m, t}^{*}(j)$ in terms of the foreign currency. The demand curve facing each monopolistically competitive exporter is given by

$$
y_{x, t}(j)=\left(\frac{P_{m, t}^{*}(j)}{P_{m, t}^{*}}\right)^{-\eta_{x, t}} y_{x, t},
$$

where $y_{x, t}$ is aggregate exports, and $\eta_{x, t}$ is a time-varying elasticity of substitution between the differentiated goods. To capture cost-push shocks, we specify an exogenous $\mathrm{AR}(1)$ process on $\theta_{x, t}=$ $\eta_{x, t} /\left(\eta_{x, t}-1\right)$

$$
\log \theta_{x, t}=\left(1-\rho_{x}\right) \log \theta_{x}+\rho_{x} \log \theta_{x, t-1}+\varepsilon_{x, t},
$$

where $\theta_{x}$ is the gross markup of export prices over the domestic-goods price at the steady state.

The exporter's real profit at period $t$ in terms of the foreign currency is given by

$$
\frac{\Pi_{x, t}(j)}{P_{t}^{*}}=\frac{P_{m, t}^{*}(j)}{P_{t}^{*}} y_{x, t}(j)-\frac{P_{x, t} / e_{t}}{P_{t}^{*}} y_{x, t}(j)-\text { adj. costs, }
$$

where $\kappa_{x}$ and $\varsigma_{x}$ are the level and indexation parameters, respectively, for the quadratic price adjustment costs. Similar to the importers' problem, the optimality conditions of exporters yield (after log-linearization) a New Keynesian Phillips curve for export prices:

$$
\widehat{\pi}_{m, t}^{*}=\frac{\beta_{P}}{1+\beta_{P} \varsigma_{x}} E_{t} \widehat{\pi}_{m, t+1}^{*}+\frac{\varsigma_{x}}{1+\beta_{P} \varsigma_{x}} \widehat{\pi}_{m, t-1}^{*}-\frac{1}{\left(1+\beta_{P} \varsigma_{x}\right) \kappa_{x}}\left(\widehat{p}_{m, t}^{*}+\widehat{r e r}_{t}-\widehat{p}_{x, t}-\widehat{\theta}_{x, t}\right),
$$

where $p_{m, t}^{*}=P_{m, t}^{*} / P_{t}^{*}$ is the relative price of exports in the foreign country. Similar to importers, exporters charge a markup over the domestic price when they export the good abroad, but this markup varies over time due to price adjustment costs and the presence of exogenous markup shocks. Variations in the domestic price are only slowly reflected in export prices due to the presence of nominal rigidities.

Foreign demand for the domestic economy's exports is modelled in reduced form as

$$
y_{x, t}=y_{x, t-1}^{\zeta^{*}}\left[\phi^{*}\left(p_{m, t}^{*}\right)^{-\eta^{*}} y_{t}^{*}\right]^{1-\zeta^{*}} \widetilde{\varepsilon}_{x, t}
$$

where exports depend on past exports, the relative price of exports and foreign output. $\zeta^{*}$ determines the persistence of exports, and captures the habit formation of foreigners for domestic goods. $y_{t}^{*}$ is the foreign output level, $\eta^{*}$ determines the elasticity of exports with respect to the relative price and $\phi^{*}$ is a level parameter. $\widetilde{\varepsilon}_{x, t}$ is an exogenous export demand shock given by an $\operatorname{AR}(1)$ process. Note that the balance-of-payments identity in the model is given by

$$
\frac{e_{t} B_{t}^{*}}{\varkappa_{t} \Phi_{t} R_{t}^{*} P_{t}}-\frac{e_{t} B_{t-1}^{*}}{P_{t}}=\frac{P_{x, t}}{P_{t}} y_{x, t}-\frac{e_{t} P_{t}^{*}}{P_{t}} y_{m, t}
$$




\subsection{Capital and housing producers}

\subsubsection{Capital producers}

Capital producers are perfectly competitive. After goods production takes place, these firms purchase the undepreciated part of the installed capital from patient households and entrepreneurs at a relative price of $q_{k, t}$, and the new capital investment goods from final-goods firms at a relative price of $p_{i k, t}$, and produce the capital stock to be carried over to the next period. This production is subject to adjustment costs in the change in investment, and is described by the following law of motion for capital:

$$
k_{t}=\left(1-\delta_{k}\right) \psi_{k, t} k_{t-1}+z_{k, t} i_{k, t}-\frac{\kappa_{k}}{2}\left(\frac{i_{k, t}}{i_{k, t-1}}-1\right)^{2} z_{k, t} i_{k, t},
$$

where $k_{t}=k_{P, t}+k_{E, t}$, and $\kappa_{k}$ is the adjustment cost parameter. $z_{k, t}$ captures investment-specific technological change, which is assumed to be exogenous and follows an $\operatorname{AR}(1)$ process.

After capital production, the end-of-period installed capital stock is sold back to patient households and entrepreneurs at the installed capital price of $q_{k, t}$. The capital producers' objective is thus to maximize

$$
E_{t} \sum_{\tau=t}^{\infty} \beta_{P}^{\tau-t} \frac{\lambda_{P, \tau}}{\lambda_{P, t}}\left[q_{k, \tau} k_{\tau}-q_{k, \tau}\left(1-\delta_{k}\right) \psi_{\tau} k_{\tau-1}-\frac{P_{i k, \tau}}{P_{t}} i_{k, \tau}\right],
$$

subject to the law of motion for capital, where future profits are again discounted using the patient households' stochastic discount factor. The first-order condition (after log-linearization) of capital producers yields a $q$-equation of investment:

$$
\widehat{i}_{k, t}=\frac{\beta_{P}}{1+\beta_{P}} E_{t} \widehat{i}_{k, t+1}+\frac{1}{1+\beta_{P}} \widehat{i}_{k, t-1}+\frac{1}{\left(1+\beta_{P}\right) \kappa_{k}}\left(\widehat{q}_{k, t}+\widehat{z}_{k, t}-\widehat{p}_{i k, t}\right) .
$$

\subsubsection{Housing producers}

Housing producers are modelled analogous to capital producers. The law of motion for housing is given by

$$
h_{t}=\left(1-\delta_{h}\right) \psi_{h, t} h_{t-1}+z_{h, t} i_{h, t}-\frac{\kappa_{h}}{2}\left(\frac{i_{h, t}}{i_{h, t-1}}-1\right)^{2} z_{h, t} i_{h, t}
$$

where $h_{t}=h_{P, t}+h_{I, t}$, and $\kappa_{h}$ is the adjustment cost parameter. $z_{h, t}$ captures investment-specific technological change in housing, which is assumed to be exogenous and follows an $\mathrm{AR}(1)$ process. Similar to capital producers, the first-order condition of housing producers yields a $q$-equation for housing investment demand:

$$
\widehat{i}_{h, t}=\frac{\beta_{P}}{1+\beta_{P}} E_{t} \widehat{i}_{h, t+1}+\frac{1}{1+\beta_{P}} \widehat{i}_{h, t-1}+\frac{1}{\left(1+\beta_{P}\right) \kappa_{h}}\left(\widehat{q}_{h, t}+\widehat{z}_{h, t}-\widehat{p}_{i h, t}\right) .
$$




\subsection{Monetary, fiscal and macroprudential policy}

The central bank targets the nominal interest rate using a Taylor rule,

$$
\log R_{t}=\rho \log R_{t-1}+(1-\rho)\left[\log R+a_{\pi} \log \frac{\pi_{t}}{\pi}+a_{y} \log \frac{y_{t}}{y}\right]+\widetilde{\varepsilon}_{r, t}
$$

where $R$ is the steady-state value of the (gross) nominal policy rate, $\rho$ determines the extent of interest rate smoothing, and the parameters $a_{\pi}$ and $a_{y}$ determine the importance of inflation and the output gap in the Taylor rule. $\widetilde{\varepsilon}_{r, t}$ is the monetary policy shock, which follows an $\mathrm{AR}(1)$ process.

The government's budget constraint is given by

$$
\begin{aligned}
g_{t}+\operatorname{tr}_{P, t} & +\operatorname{tr}_{I, t}+\frac{B_{t-1}(i)}{P_{t}} \\
& =\tau_{l, t}\left(w_{P, t} l_{P, t}+w_{I, t} l_{I, t}\right)+\tau_{k, t}\left(r_{k P, t} k_{P, t-1}+r_{k E, t} k_{E, t-1}\right) \psi_{k, t}+\frac{B_{t}(i)}{R_{t} P_{t}},
\end{aligned}
$$

where final government expenditure, $g_{t}$, follows an exogenous $\operatorname{AR}(1)$ process:

$$
\log g_{t}=\left(1-\rho_{g}\right) \log g+\rho_{g} \log g_{t-1}+\varepsilon_{g, t}
$$

Transfer payments to households are given by

$$
t r_{i, t}=\Xi_{i} y_{d}\left(\frac{y_{t}}{y}\right)^{-\varrho_{y}} \widetilde{\varepsilon}_{t r, t}-\varrho_{b} b_{t-1}^{g}, \text { for } i=P, I,
$$

where $\Xi_{P}$ and $\Xi_{I}$ are level parameters, $\varrho_{y}$ is the automatic stabilizer component of transfers, and $\varrho_{b}$ determines the response of transfers to government debt. ${ }^{11}$ Note that, with our specification, an increase in tax revenue would be used to retire government debt and slowly increase transfers to each type of household.

To capture possibly countercyclical macroprudential policy, we allow regulatory bank capital and LTV ratios to respond to total and household credit gaps, respectively:

$$
\begin{aligned}
\gamma_{t} & =\gamma+\alpha_{\gamma}\left(\frac{b_{t}}{y_{t}}-\frac{b}{y}\right)+\widetilde{\varepsilon}_{\gamma, t}, \\
m_{I, t} & =m_{I}-\alpha_{m}\left(\frac{p_{I, t} b_{I, t}}{y_{t}}-\frac{p_{I} b_{I}}{y}\right)+\widetilde{\varepsilon}_{m, t},
\end{aligned}
$$

where the market value of total bank credit is given by $b_{t}=p_{I, t} b_{I, t}+p_{E, t} b_{E, t}$, and $\alpha_{\gamma}$ and $\alpha_{m}$ measure the sensitivity of each countercyclical policy to the corresponding credit gap.

\footnotetext{
${ }^{11}$ Either taxes, government expenditure or transfers need to adjust with the level of government debt, so that the government cannot run a Ponzi scheme. We choose to make the adjustment through transfers based on the results of Leeper et al. (2010).
} 


\subsection{Market clearing conditions}

The intermediate domestic goods are used in the final-goods production for consumption, capital investment, housing investment, government expenditure and exports: ${ }^{12}$

$$
c_{d, t}+i_{k d, t}+i_{h d, t}+g_{d, t}+y_{x d, t}=y_{d, t} .
$$

Similarly, the intermediate imported goods are used by final-goods producers as

$$
c_{m, t}+i_{k m, t}+i_{h m, t}+g_{m, t}+y_{x m, t}=y_{m, t} .
$$

The model's equilibrium is defined as prices and allocations such that households maximize the discounted present value of utility, banks and entrepreneurs maximize the discounted present value of dividends, and all firms maximize the discounted present value of profits, subject to their constraints, and all markets clear.

\section{Calibration}

We calibrate the parameters that pin down the model's steady-state ratios in order to match data targets obtained using averages from the Canadian National Income Accounts and Financial Flow Accounts since the start of the inflation-targeting period in Canada (1991Q1-2012Q4). ${ }^{13}$ For the parameters that mainly determine dynamics, we pick values from related literature and models currently used at the Bank. Table 1 summarizes the list of parameter values, and Table 2 lists the implied steady-state ratios of the model.

The trend inflation factor, $\pi$, is set to 1.005 , corresponding to a $2 \%$ annual inflation target. The time-discount factors of patient and impatient households, $\beta_{P}$ and $\beta_{I}$, are set to match an annualized 3\% real risk-free interest rate, and a total spread on household loans of $240 \mathrm{bp}$, the latter based on data for the effective household borrowing rate. Similarly, the discount rates for banks and entrepreneurs, $\beta_{B}$ and $\beta_{E}$, are set to match a $14 \mathrm{bp}$ funding spread for banks, and a $200 \mathrm{bp}$ total spread on entrepreneurial loans, based on data for the 3-month bankers' acceptance rate and the effective business borrowing rate.

The inverse of labor supply elasticity, $\vartheta$, is set to 5 to ensure a Frisch elasticity of labor supply of 0.2 , as in Smets and Wouters (2007). Similarly, the habit parameter for consumption, $\zeta$, is set to 0.94, as in ToTEM II (Dorich et al., 2013). The level parameters for housing in the utility function, $\xi_{h P}$ and $\xi_{h I}$, are calibrated to ensure that the total housing value is 1.5 times the annual GDP, and impatient households own about $32 \%$ of the total housing. At the steady state of the model, households altogether have $70 \%$ equity in total housing, and the ratio of quarterly consumption to housing is around 0.1, consistent with the Financial Flow Accounts data and Basant Roi and

\footnotetext{
${ }^{12}$ Utilization costs and financial costs are modelled as transfer payments to patient households.

${ }^{13}$ Inflation targeting was adopted in Canada in February 1991.
} 
Mendes (2007). The level parameters for labor supply, $\xi_{l P}$ and $\xi_{l I}$, are calibrated to ensure that labor supply is equal to 1 at the steady state for both types of households.

According to Canadian Financial Flow and National Accounts data, residential and business investment relative to output are about $6.5 \%$ and $12.2 \%$, while housing-to-GDP and capital-toGDP ratios are about 1.5 and 2.0 on an annualized basis. Based on these, we calibrate the quarterly depreciation rates for housing and capital stocks, $\delta_{h}$ and $\delta_{k}$, to $1.08 \%$ and $1.53 \%$, respectively. The share of capital in domestic production, $\alpha$, is set to 0.3 , implying an income share of labor equal to $70 \%$. We set the capital share of patient households, $\mu_{k}$, to 0.43 to match a $75 \%$ equity share in total capital, while entrepreneurs' equity share in their own capital, $1-m_{E}$, is $50 \% .{ }^{14}$ We set the wage share of patient households, $\mu_{l}$, to 0.68 , and the transfer-to-output ratio for impatient households, $\Xi_{I}$, is calibrated to ensure that the shares of impatient households in total wage income and total consumption are both $32 \%$, similar to their share in total housing.

The shares of imported goods in final-goods production, $\phi_{c}, \phi_{i k}, \phi_{i h}, \phi_{g}$ and $\phi_{x}$, are set to 0.3 , $0.18,0,0.08$ and 0.33 , respectively, similar to values used in ToTEM II. The implied aggregate import-to-GDP ratio is $32 \%$. The elasticities of substitution between domestic and foreign goods, $\eta_{c}, \eta_{i k}, \eta_{i h}, \eta_{g}$ and $\eta_{x}$, are all set to 0.5 , also following ToTEM II. The elasticity of the exchange rate to the net foreign asset position, $\Phi_{a}$, is set to 0.003 , while the backward-looking component, $\Phi_{e}$, is set to 0.25 in the benchmark calibration, between the values used in ToTEM (Murchison and Rennison, 2006) and ToTEM II. For the export demand specification, the persistence parameter, $\zeta^{*}$, is set to 0.8 , while the elasticity with respect to the relative price, $\eta^{*}$, is set to 1.5 , following corresponding figures in ToTEM II. The level parameter for exports, $\phi^{*}$, is set to 0.32 , to ensure that there is balanced trade at the steady state of the model.

The price and wage markup parameters, $\theta_{w}, \theta_{d}, \theta_{m}$ and $\theta_{x}$, are all set to 1.25 , to reflect $25 \%$ markup. The price and wage adjustment cost parameters, $\kappa_{w}, \kappa_{d}, \kappa_{m}$ and $\kappa_{x}$, are set to 333, 84, 84 and 2, respectively, based on the slopes of Phillips curves in ToTEM II, while the indexation parameters, $\varsigma_{w}, \varsigma_{d}, \varsigma_{m}$ and $\varsigma_{x}$, are set to 0.5 . The inverse of the elasticity of the utilization rate to the rental rate of capital, $\varpi$, is set to 5 , similar to ToTEM, while the level parameters in the utilization cost specification, $\kappa_{u P}$ and $\kappa_{u E}$, are calibrated to ensure that the utilization rate of each type of capital is equal to 1 at the steady state. The investment adjustment costs, $\kappa_{k}$ and $\kappa_{h}$, are set to 6 , implying that the elasticity of investment demand to Tobin's $q$ is around 0.08 , similar to Smets and Wouters (2007). ${ }^{15}$

For the financial parameters, the coupon rates for the long-term bank loans, $\delta_{I}$ and $\delta_{E}$, are set

\footnotetext{
${ }^{14}$ The debt-to-asset ratio of non-financial corporations is around 0.5 in the Financial Flow Accounts of Canada when we consider only the liability side of the balance sheet. If we subtract financial assets from debt, then the net debt-to-asset ratio is close to 0 , and recently negative. We therefore target a total debt-to-asset ratio of 0.25 for capital owners. Also note that the steady-state loan-to-value ratio for business loans, $m_{E}$, is set to 0.5 , as in Bernanke et al. (1999), reflecting a debt-to-equity ratio of 1 for borrowing firms.

${ }^{15}$ The adjustment costs for the housing and capital stocks of patient households, $\kappa_{h P}$ and $\kappa_{k P}$, are set to 50 in the benchmark calibration, to ensure slow adjustment in the distribution of real assets across the different types of agents. The dividend adjustment cost parameters for banks and entrepreneurs, $\kappa_{d B}$ and $\kappa_{d E}$, are also set to 50, to capture dividend smoothing observed in the data (Jermann and Quadrini, 2012).
} 
to 0.97 and 0.92 , reflecting average loan lives of 20 and 10 quarters, respectively. The elasticity of monitoring costs with respect to bank leverage, $\chi_{d 2}$, is set to 0.002 , while the elasticity of monitoring costs with respect to bank capital regulations, $\chi_{d 3}$, is set to 0.01 . The latter is calibrated such that a 1 pp increase in bank capital requirements reduces output by about 0.35 per cent, consistent with the Macroeconomic Assessment Group (MAG) report of the Financial Stability Board and the Basel Committee on Banking Supervision (BIS, 2010), while the former ensures a more limited role for the bank capital channel in the benchmark case. ${ }^{16}$ Similarly, the elasticity of monitoring costs with respect to impatient households' leverage, $\chi_{I 2}$, is set to 0.005 , to ensure that reducing LTV from 0.95 to 0.9 would result in an 80 bp increase in the household loan rate, consistent with estimates in the literature. This also implies a 1.6 per cent decline in household debt in the first year, largely consistent with the estimates from the Bank of Canada's micro-data-based Household Risk Assessment Model (HRAM) (Faruqui et al., 2012). The monitoring cost elasticity for business loans, $\chi_{E 2}$, is set to 0.05 , similar to Bernanke et al. (1999). This also ensures that a $1 \mathrm{pp}$ increase in capital requirements leads to a $28 \mathrm{bp}$ increase in the spread faced by entrepreneurs at impact, largely consistent with the MAG report. ${ }^{17}$

For the policy parameters, the steady-state LTV ratio, $m_{I}$, is set to 0.95 , which is the maximum LTV allowed for first-time homebuyers in Canada since 2009. ${ }^{18}$ The bank capital requirement ratio, $\gamma$, is set to 0.1 , and the risk weights that apply to capital requirements, $\omega_{I}$ and $\omega_{E}$, are set to 0.5 and 1 for household and business loans, respectively, consistent with Basel III regulations. In the benchmark calibration, we set the countercyclicality parameters for macroprudential policy, $\alpha_{\gamma}$ and $\alpha_{m}$, to 0 . The smoothing parameter in the monetary policy rule, $\rho$, is set to 0.75 , the long-run response coefficient for inflation, $a_{\pi}$, is set to 2.5, similar to ToTEM, while the output response coefficient in the Taylor rule is set to 0 in the benchmark calibration. The government's share in output, $g / y$, is 0.23 , while labor and capital income tax rates, $\tau_{l}$ and $\tau_{k}$, are set to 0.3 and 0.55 , respectively, the latter being calibrated using the data targets for capital-output and investmentoutput ratios and the model-implied rental rates of capital.

The persistence parameters for the macroprudential policy shocks are set arbitrarily close to 1 (i.e., these are permanent shocks), while the persistence parameter for the monetary policy shock is set to 0.15. For the capital quality and exuberance shocks, as well as the preference and riskappetite shocks, the persistence parameters are set to 0.5. For the rest of the shocks, the persistence

\footnotetext{
${ }^{16}$ Setting $\chi_{d 2}$ to 0.01 would lead to an overstated role for the bank capital channel, while setting $\chi_{d 3}$ to 0.002 would imply that capital regulations are far less effective than what is implied by the MAG report. Given these considerations, we decided to have a more flexible specification for banks' funding spread.

${ }^{17}$ The level parameters in the monitoring cost specifications, $\chi_{d 1}, \chi_{I 1}$ and $\chi_{E 1}$, are calibrated such that they are consistent with the steady-state funding and lending spreads reported previously. The elasticity parameter in the portfolio preference term of investors, $\varrho_{\varkappa}$, is set to 0 in the benchmark calibration.

${ }^{18}$ Three-fourths of all Canada Mortgage and Housing Corporation (CMHC) originations for first-time homebuyers have LTVs at the regulatory maximum. The average LTV for first-time homebuyers is around 0.934, slightly lower than the regulatory maximum, while survey evidence suggests that around $40 \%$ of borrowers also borrow part of their downpayments, which are not reflected in these numbers. Note that $75 \%$ of CMHC mortgage originations for first-time homebuyers had LTVs close to 0.95 , the regulatory maximum, since 2009. $20 \%$ of mortgages had LTVs close to 0.9 , and only about $5 \%$ had lower LTVs.
} 
parameters are set to 0.9 .

\section{Results}

In this section, we discuss the transmission of key financial shocks using impulse-response functions, and illustrate how the bank capital and risk-taking channels can provide amplification in the model. We then examine the effects of macroprudential regulations and monetary policy, and compare their effects on household debt and output.

\subsection{Transmission of spread shocks and amplification channels}

To illustrate how shocks are transmitted to the rest of the economy in the model, we first consider the effects of a (positive) 100 bp shock to banks' funding spread, $\widetilde{\varepsilon}_{d, t}$ (Figure 3). The increase in the funding rate, $R_{d, t}$, is only partially passed through to the borrowing rates faced by impatient households and entrepreneurs, $R_{I, t}$ and $R_{E, t}$, respectively. In particular, the household and business loan rates increase by $23 \mathrm{bp}$ and $38 \mathrm{bp}$, respectively; household loan rates respond less, since they are of longer duration. The increase in loan rates leads borrowers to reduce the amount of bank loans, $b_{I, t}$ and $b_{E, t}$, which in turn leads them to reduce their holdings of housing and capital, $h_{I, t}$ and $k_{E, t}$, as well as their consumption, $c_{I, t}$. This leads to a decline in demand for investment goods, $i_{k, t}$ and $i_{h, t}$, and to a reduction in asset prices, $q_{h, t}$ and $q_{k, t}$. The overall impact of the shock is to decrease aggregate output, $y_{t}$, along with a decline in wages and inflation, $\pi_{t}$. The policy rate, $R_{t}$, is reduced as a result of the decline in inflation, which leads to capital outflows. This depreciates the currency in real terms and increases exports. Also, the decline in asset prices incentivizes patient households to increase purchases of housing and capital. These general-equilibrium effects help dampen the adverse effects of the shock. On the other hand, the fall in asset prices leads to an increase in the leverage of borrowers, and therefore an increase in banks' monitoring costs. This amplifies the effects of the shock on lending rates, since the increase in monitoring costs is reflected in lending rates $R_{I, t}$ and $R_{E, t}$. This is the well-known financial accelerator (i.e., balance-sheet channel). There is, however, an additional amplification in the model that is due to the bank capital channel. The fall in asset prices also leads to a reduction in the prices of long-term assets held by banks. Coupled with the increase in their monitoring costs, bank capital is adversely affected as a result of the shock. This leads to an increase in the banks' funding rate, $R_{d, t}$, above and beyond what would be generated in the absence of the bank capital channel.

To illustrate the amplification provided by the bank capital channel, we now consider the impulse responses from a (negative) $100 \mathrm{bp}$ shock to the mortgage spread, $\widetilde{\varepsilon}_{I, t}$. Figure 4 plots the impulse responses of key variables in the model in the benchmark case where the bank capital channel is present (i.e., the elasticity parameter on the funding spread, $\chi_{d 2}=0.02$ ), and compares it to a case where the bank capital channel is absent (i.e., $\left.\chi_{d 2}=0\right) .{ }^{19}$ In the benchmark case, the decline

\footnotetext{
${ }^{19}$ The usual financial accelerator arising from the borrower balance-sheet channel is nevertheless present in both.
} 
in the lending rate faced by impatient households, $R_{I, t}$, induces them to increase their borrowing, $b_{I, t}$, and their demand for housing and consumption, $h_{I, t}$ and $c_{I, t}$, respectively. The increase in housing demand translates into a rise in overall residential investment, $i_{h, t}$, and house prices, $q_{h, t}$. The increase in demand for consumption and residential investment goods also leads to an increase in business investment, $i_{k, t}$, and capital prices, $q_{k, t}$. Thus, the overall impact of the shock on the economy is to raise aggregate output, $y_{t}$, which is accompanied by an increase in inflation, $\pi_{t}$, since the derived demand for labor also increases along with wages. The pickup in inflation prompts the central bank to raise the policy rate, $R_{t}$. This prompts patient households to curtail their consumption expenditures, $c_{P, t}$, but aggregate consumption, $c_{t}$, increases nevertheless, due to the demand generated from impatient households. Also, the increase in housing and capital prices induces patient households to reduce their holdings of housing and capital, $h_{P, t}$ and $k_{P, t}$, but not by so much that it changes the overall direction of residential and business investment. These general-equilibrium effects on patient households' consumption and housing demand help moderate the effects of the shock on the real economy. Another moderating factor is the resulting capital inflows, which lead to an appreciation in the real exchange rate, rer $_{t}$, and a decrease in exports, $y_{x, t}$. On the other hand, the increase in asset prices leads to an increase in the price of long-term assets held by banks and decreases their monitoring costs, inducing an increase in bank capital, $a_{t}$. This reduces banks' funding rate, $R_{d, t}$, despite the rise in the policy rate, which translates into lower lending rates in the economy for both household and business borrowers. This last channel is absent when we set $\chi_{d 2}$ equal to 0 . In particular, the funding rate moves along with the policy rate, and thus business loans slightly decline due to the rise in the policy rate. Capital investment declines more overall as patient households also decrease their capital holdings, and capital prices decline as a result of the decline in demand. In the absence of the bank capital channel, sector-specific shocks such as the mortgage spread shock do not necessarily lead to a co-movement between residential and non-residential investment, or between mortgage and business loans. The presence of the bank capital channel is key to generate these co-movements. ${ }^{20}$

Although we abstract from the effects of the risk-taking channel in our benchmark calibration (i.e., we set $\varrho_{\varkappa}=0$ in equation (9)), we illustrate how it can potentially generate further amplification in the system by setting $\varrho_{\varkappa}$ to 0.05 in Figure 5, and consider a (negative) $100 \mathrm{bp}$ shock to the business spread, $\widetilde{\varepsilon}_{E, t}$. In the benchmark case, the effects of the shock are qualitatively similar to the mortgage spread shock described above, but the effects are relatively stronger for the business loans and investment, rather than for household loans and residential investment. When the risk-taking channel is on, the pickup in real activity reduces $\varkappa_{t}$, and prompts savers to rebalance their portfolios toward riskier assets (i.e., away from short-term government bonds, and toward bank deposits and capital). This effect reduces the funding spread, and leads to a reduction in the funding rate of banks, $R_{d, t}$, despite the increase in the policy rate, $R_{t}$. As a result, the lending rates of banks, $R_{I, t}$

\footnotetext{
${ }^{20}$ Part of the co-movement is due to the effects of the decline in demand for residential investment on overall output, and firms' demand for new capital. This channel, however, is not sufficient to generate co-movement in the absence of the bank capital channel.
} 
and $R_{E, t}$, decline more, and asset prices, $q_{h, t}$ and $q_{k, t}$, increase further than the benchmark case. Thus, borrowers also further increase their demand for housing and capital purchases, $h_{I, t}$ and $k_{E, t}$, as well as consumption, $c_{I, t}$. The decline in $\varkappa_{t}$ also reduces the rate at which patient households discount future returns, thus leading them to increase their consumption demand, $c_{P, t}$, resulting in a substantial increase in aggregate consumption, $c_{t}$. In summary, the overall effect of the risk-taking channel is to amplify the effects of the shock, including its effects on output, $y_{t}$, and inflation, $\pi_{t}$, separately from the amplification provided by the balance-sheet and bank capital channels.

\subsection{The effects of exuberance and risk-appetite shocks}

In this subsection, we illustrate how our model can help explain the buildup of financial imbalances by analyzing the impact of housing and capital exuberance shocks and a shock to the risk appetite of patient households.

Figure 6 plots the effects of an increase in exuberance for housing, $\varkappa_{h, t}$. Recall that the housing exuberance shock causes private agents to expect higher capital gains from housing than would actually be realized. The increase in expected returns from housing leads to an increase in the current price of housing, $q_{h, t}$. This reduces the leverage of impatient households, lowering the monitoring costs of banks, which leads to a decline in the lending rate faced by impatient households, $R_{I, t}$. As the balance sheets of impatient households improve, banks' funding costs are reduced, benefiting the non-housing sector as well as the housing sector. The shock leads to an overall increase in residential investment, $i_{h, t}$, and consumption, $c_{t}$, increasing aggregate output, $y_{t}$, and inflation, $\pi_{t}$. The increase in the policy rate, $R_{t}$, and the appreciation in the exchange rate, rer $_{t}$, help moderate the positive effects of the shock on the economy.

Similarly, in Figure 7 we consider the effects of an increase in exuberance for capital, $\varkappa_{k, t}$, where agents expect higher capital gains from their investments than would actually be realized. The results are qualitatively very similar to an exuberance shock to housing, except that the relative effects of the shock are much larger for business loans and capital investment, rather than the stronger effects observed for household loans and residential investment in Figure 6.

Figure 8 plots the impulse responses from a shock to the risk appetite of patient households, $\varkappa_{t}$, which is the risk premium shock considered in Smets and Wouters (2007). Similar to the risk-taking channel mechanism described in the previous subsection, the decline in $\varkappa_{t}$ prompts investors to rebalance their portfolios toward riskier assets, including bank deposits, and reduces the funding rate of banks, $R_{d, t}$. As a result, lending rates $R_{I, t}$ and $R_{E, t}$ decline, increasing borrowers' demand for consumption, housing and capital purchases. The increase in house prices prompts patient households to reduce their holdings of housing. This, along with the increase in the policy rate, $R_{t}$, and the appreciation in the real exchange rate, moderates the effects of the risk-appetite shock, but, overall, output, $y_{t}$, rises, along with inflation, $\pi_{t}$. 


\subsection{The effects of macroprudential regulations and monetary policy}

In Figure 9, we consider a permanent tightening in the regulatory LTV ratio, $m_{I, t}$, by 5 pp (from $95 \%$ to $90 \%$ ). The increase in required housing equity leads to an increase in the current and expected monitoring costs of banks, $\Upsilon_{I, t}$. This in turn leads to an increase in the lending rate faced by impatient households, $R_{I, t}$, inducing them to reduce their borrowing, $b_{I, t}$, and their demand for housing and consumption, $h_{I, t}$ and $c_{I, t}$, respectively. The decline in housing demand translates into a reduction in overall residential investment, $i_{h, t}$, and a decline in housing prices, $q_{h, t}$. The reduction in demand for consumption and residential investment goods also leads to a reduction in business investment, $i_{k, t}$, along with a decline in capital prices, $q_{k, t}$, as businesses find themselves with excess capital. Thus, the overall impact of the LTV policy on the economy is to reduce aggregate output, $y_{t}$, which is accompanied by a decline in inflation, $\pi_{t}$, as the derived demand for labor declines and wages fall. The fall in inflation prompts the central bank to reduce the policy rate, $R_{t}$. This prompts patient households to increase their consumption expenditures, $c_{P, t}$, but aggregate consumption, $c_{t}$, declines nevertheless, due to the decline in impatient households' consumption. Also, the decline in housing and capital prices induces patient households to increase their purchases of housing and capital, $h_{P, t}$ and $k_{P, t}$, but not by so much that it changes the overall direction of residential and business investment. These general-equilibrium effects on patient households' consumption and housing demand help contain the adverse effects of the LTV policy change on the economy. Another moderating factor is the resulting capital outflows, which lead to a depreciation in the real exchange rate, $r e r_{t}$, and an increase in exports, $y_{x, t}$. On the other hand, the decline in asset prices leads to a reduction in the price of long-term assets held by banks, and increases their monitoring costs, inducing a decline in bank capital, $a_{t}$. This raises banks' funding rate, $R_{d, t}$, despite the decline in the policy rate, which translates into higher lending rates in the economy, and helps exacerbate the adverse effects of the LTV policy change.

In Figure 10, we consider a permanent increase in the regulatory bank capital requirement ratio, $\gamma_{t}$, by 1 pp (from $10 \%$ to 11\%). The increase in regulatory bank capital leads to an increase in the spread faced by banks, $\Upsilon_{d, t}$, given that they have insufficient net worth at impact. This leads to an increase in the funding rate, $R_{d, t}$, which is partially passed through to the borrowing rates faced by impatient households and entrepreneurs, $R_{I, t}$ and $R_{E, t}$, respectively. As a result, the amount of bank loans, $b_{I, t}$ and $b_{E, t}$, declines, and borrowers are forced to reduce their holdings of housing and capital, $h_{I, t}$ and $k_{E, t}$, as well as their consumption, $c_{I, t}$. This leads to a decline in demand for investment goods, $i_{k, t}$ and $i_{h, t}$, and to a reduction in asset prices, $q_{h, t}$ and $q_{k, t}$. As in the case of the LTV policy, the overall impact of the capital regulatory policy is to decrease aggregate output, $y_{t}$, along with a decline in wages and inflation, $\pi_{t}$. Again, the purchases of consumption, housing and capital by patient households due to falling asset prices and the decline in the policy rate, along with depreciation in the real exchange rate in the short run, dampen the adverse effects of the regulatory change in bank capital requirements. On the other hand, the fall in asset prices leads to a reduction in the price of long-term assets held by banks, and to an increase in monitoring costs incurred by 
banks, which complicates their efforts to recapitalize. This keeps banks' funding rate, $R_{d, t}$, higher than it would otherwise be, and amplifies the adverse effects of the regulatory change.

Figure 11 plots the impulse responses of model variables to a $100 \mathrm{bp}$ (annualized) shock to the policy rate, $\widetilde{\varepsilon}_{r, t} \cdot{ }^{21}$ Note that the long-term rates faced by households, $R_{I, t}$, and entrepreneurs, $R_{E, t}$, increase by only a fraction of the change in the policy rate, since the policy rate is expected to slowly decline from its peak. Facing higher rates, both impatient households and entrepreneurs reduce their borrowing, $b_{I, t}$ and $b_{E, t}$, and their purchases of housing and capital, $h_{I, t}$ and $k_{E, t}$, respectively. Impatient households also reduce their consumption expenditures, $c_{I, t}$. As before, these effects lead to a reduction in overall residential and business investment activity, $i_{h, t}$ and $i_{k, t}$, along with a reduction in aggregate output, $y_{t}$, and inflation, $\pi_{t}$. Also as before, the fall in asset prices, $q_{h, t}$ and $q_{k, t}$, leads to an increase in the monitoring cost of banks, amplifying the adverse effects of the monetary shock. Note, however, that some of the factors that helped moderate the effects of macroprudential policies now work in the opposite direction, and exacerbate the situation. In particular, the increase in the policy rate leads to a reduction in the consumption demand of patient households, $c_{P, t}$, and to a real appreciation of currency, leading to a fall in exports, $y_{x, t}$.

\subsubsection{Comparing the effects of macroprudential and monetary policies on household debt}

The impulse responses described above suggest that all three tools (regulatory LTV, capital requirements and monetary policy) can be utilized to reduce household debt, but their respective costs in terms of the reduction in output are quite different (Table 3). In particular, a 5 pp tightening in regulatory LTV decreases household debt by 1.6 per cent in the first year of the policy change, and reduces it by another 6 per cent at the peak during the transition path. The output impact at the peak is about 0.7 per cent. In contrast, a 1 pp increase in capital requirements reduces household debt by about 1.4 per cent, while reducing output by about 0.35 per cent at the peak. Thus, an increase of about $2 \mathrm{pp}$ in bank capital would have the same impact on output as a 5 pp reduction in LTV, but its impact on household debt would be about half of LTV at the peak. ${ }^{22}$ Similarly, a 100 bp temporary increase in the policy rate reduces household debt by about 0.5 per cent at the peak, but this comes at an output cost of about 0.4 per cent, offering an even worse trade-off than capital requirements in terms of reducing household debt.

In summary, among the three policies, regulatory LTV is identified as the most effective policy for reducing household indebtedness with the least output cost, followed by capital requirements

\footnotetext{
${ }^{21}$ Inflation is reduced as a result of the decrease in demand and the appreciation of currency, which induces the policy rate to increase slightly less than the monetary policy shock of $100 \mathrm{bp}$ at impact.

${ }^{22}$ Among the two macroprudential policies considered here, only the LTV policy has a permanent impact on the level of household debt in the long run. In particular, with a 5 pp permanent reduction in LTV, household debt is permanently lower by 4.8 per cent at the terminal steady state relative to its value at the initial steady state. Although capital regulations are also permanent changes, their impact on household debt is temporary, since in the long run the banks' cost of debt versus equity is equalized, given the temporary nature of dividend adjustment costs. Thus, at the terminal steady state, banks increase their bank capital and reduce the level of funding through deposits, while keeping the size of their balance sheets, and the level of their lending, the same as in the initial steady state.
} 
and monetary policy, respectively. LTV policy is a targeted tool with respect to household debt, directly affecting the source of the issue (i.e., the borrowing of impatient households). The effects of LTV do spill over to other parts of the economy as the decline in consumption and housing demand of impatient households affects entrepreneurs' demand for capital. The decline in asset prices also affects banks' capital position and their funding costs. Nevertheless, the overall impact of the LTV policy is more contained within the residential sector, and is partly offset by the increased demand for consumption and housing by patient households, and the increased export demand due to real depreciation. This is in contrast to bank capital regulations, which directly affect the business sector as well as borrower households; in particular, capital regulations have a direct impact on the borrowing costs of entrepreneurs, leading to a faster decline in entrepreneurial loans, business investment and the price of capital. Capital regulations therefore provide a broader tool in reducing household debt, relative to regulatory LTV policy. Finally, monetary policy provides the broadest tool in this respect, since it also adversely impacts patient households' consumption demand, as well as foreign demand for domestic goods, while also reducing household debt.

\section{Conclusion}

In this paper, we build a medium-scale small-open-economy DSGE model with nominal, real and financial frictions. In terms of modelling financial frictions, we aim to keep the model tractable and flexible, while capturing the main themes emphasized in the literature on real-financial linkages. In this paper, we primarily study the effects of financial shocks, and consider the effectiveness of macroprudential and monetary policies in reducing household debt. We find that, for reducing household indebtedness, targeted policies such as LTV regulations are the most effective and least costly, followed by bank capital regulations and monetary policy, respectively.

In future work, we plan to formally estimate the model to impose more discipline on the choice of parameters, and improve its quantitative predictions. We also plan to extend the model to capture additional financial features (e.g., currency mismatch in bank balance sheets, working capital needs of exporters), and exploit other solution techniques to better capture the effects of non-linearities (e.g., zero lower bound, time-varying risk, the effect of risk taking on the probability of crisis). 


\section{References}

[1] Adolfson, M., S. Laseen, J. Linde, and M. Villani (2008). "Evaluating an Estimated New Keynesian Small Open Economy Model," Journal of Economic Dynamics and Control, 32, 2690-2721.

[2] Adrian, T. and H. S. Shin (2010). "Liquidity and Leverage," Journal of Financial Intermediation, 19, 418-437.

[3] Aikman, D., and M. Paustian (2006). "Bank capital, asset prices and monetary policy," Bank of England Working Paper No. 305.

[4] Alpanda, S. (2013). "Identifying the Role of Risk Shocks in the Business Cycle Using Stock Price Data," Economic Inquiry, 51, 304-335.

[5] Alpanda, S., and J. Dorich (2013). "Quantitative Easing and the Financial Accelerator in a DSGE Model," mimeo, Bank of Canada.

[6] Alpanda, S., and A. Peralta-Alva (2010). "Oil Crisis, Energy-Saving Technological Change, and the Stock Market Crash of 1973-74," Review of Economic Dynamics, 13, 824-842.

[7] Alpanda, S., and S. Zubairy (2013). "Housing and Tax Policy," Bank of Canada Working Paper No. 2013-33.

[8] Amano, R., and M. Shukayev (2012). "Risk Premium Shocks and the Zero Bound on Nominal Interest Rates," Journal of Money, Credit and Banking, 44, 1475-1505.

[9] Amdur, D. (2010). "A Business Cycle Model of Aggregate Debt and Equity Flows," mimeo, Muhlenberg College.

[10] Aoki, K., J. Proudman, and G. Vlieghe (2004). "House prices, consumption, and monetary policy: a financial accelerator approach," Journal of Financial Intermediation, 13, 414-435.

[11] Bank for International Settlements (BIS) (2010). "Macroeconomic Assessment Group - Final Report: Assessing the macroeconomic impact of the transition to stronger capital and liquidity requirements," December.

[12] Basant Roi, M., and R. R. Mendes (2007). "Should Central Banks Adjust Their Target Horizons in Response to House-Price Bubbles?" Bank of Canada Discussion Paper No. 2007-4.

[13] Bernanke, B. S., and M. Gertler (1999). "Monetary Policy and Asset Price Volatility," Federal Reserve Bank of Kansas City Economic Review, fourth quarter 1999, 17-41.

[14] Bernanke, B. S., M. Gertler, and S. Gilchrist (1999). "The Financial Accelerator in a Quantitative Business Cycle Framework." in Handbook of Macroeconomics Volume 1C, ed. by J. B. Taylor and M. Woodford, 1341-93. Amsterdam: Elsevier Science, North-Holland. 
[15] Bianchi, J., and E. G. Mendoza (2010). "Overborrowing, Financial Crises and 'Macroprudential' Taxes," NBER Working Paper No. 16091.

[16] Boivin, J., T. Lane, and C. Meh (2010). "Should Monetary Policy Be Used to Counteract Financial Imbalances?" Bank of Canada Review (Summer): 23-36.

[17] Brunnermeier, M. K., and L. H. Pedersen (2008). "Market Liquidity and Funding Liquidity," Review of Financial Studies, 22, 2201-2238.

[18] Carlstrom, C. T., and T. S. Fuerst (1997). "Agency Costs, Net Worth, and Business Fluctuations: A Computable General Equilibrium Analysis," American Economic Review, 87, 893-910.

[19] Cesa-Bianchi, A. and A. Rebucci (2013). "Does Easing Monetary Policy Increase Financial Instability?" Inter-American Development Bank Working Paper Series No. 387.

[20] Chari, V. V., L. J. Christiano, and P. J. Kehoe (2007). "Business Cycle Accounting," Econometrica, 75, 781-836.

[21] Chari, V. V., and P. J. Kehoe (2009). "Bailouts, Time Inconsistency and Optimal Regulation," Federal Reserve Bank of Minneapolis Research Department Staff Report.

[22] Chatterjee, S., and B. Eyigungor (2011). "A Quantitative Analysis of the US Housing and Mortgage Markets and the Foreclosure Crisis," Federal Reserve Bank of Philadelphia Working Paper No. 11-26.

[23] Chen, H., V. Curdia, and A. Ferrero (2012). "The Macroeconomic Effects of Large-Scale Asset Purchase Programmes," Economic Journal, 122, F289-F315.

[24] Chen, N. K. (2001). "Bank net worth, asset prices and economic activity," Journal of Monetary Economics, 48, 415-436.

[25] Christensen, I., P. Corrigan, C. Mendicino, and S. Nishiyama (2009). "Consumption, Housing Collateral, and the Canadian Business Cycle," Bank of Canada Working Paper No. 2009-26.

[26] Christensen, I., and A. Dib (2008). "The Financial Accelerator in an Estimated New Keynesian Model," Review of Economic Dynamics, 11, 155-178.

[27] Christensen, I., and C. Meh (2011). "Countercyclical loan-to-value ratios and monetary policy," mimeo, Bank of Canada.

[28] Christensen, I., C. Meh, and K. Moran (2011). "Bank Leverage Regulation and Macroeconomic Dynamics," Bank of Canada Working Paper No. 2011-32.

[29] Christiano, L. J., M. Eichenbaum, and C. L. Evans (2005). "Nominal Rigidities and the Dynamic Effects of a Shock to Monetary Policy," Journal of Political Economy, 113, 1-45. 
[30] Christiano, L. J., R. Motto, and M. Rostagno (2010). "Financial Factors in Economics Fluctuations," European Central Bank Working Paper Series No. 1192 / May 2010.

[31] Cociuba, S., M. Shukayev, and A. Ueberfeldt (2011). "Do Low Interest Rates Sow the Seeds of Financial Crises?" Bank of Canada Working Paper No. 2011-31.

[32] Curdia, V., and M. Woodford (2011). "The Central Bank Balance Sheet as an Instrument of Monetary Policy," Journal of Monetary Economics, 58, 54-79.

[33] Davis, J. S. (2010). "The adverse feedback loop and the effects of risk in both the real and financial sectors," Federal Reserve Bank of Dallas Working Paper No. 66.

[34] Dell'Ariccia, G., D. Igan, L. Laeven, and H. Tong, with B. Bakker, and J. Vandenbussche (2012). "Policies for Macrofinancial Stability: How to Deal with Credit Booms," IMF working paper.

[35] De Nicolo, G., G. Favara, and L. Ratnovski (2012). "Externalities and Macroprudential Policy," IMF Staff Discussion Note.

[36] Diamond, D. W., and R. G. Rajan (2005). "Liquidity Shortages and Banking Crises," Journal of Finance, 60, 615-647.

[37] Dib, A. (2010a). "Banks, credit market frictions, and business cycles," Bank of Canada Working Paper No. 2010-24.

[38] Dib, A. (2010b). "Capital requirement and financial frictions in banking: macroeconomic implications," Bank of Canada Working Paper No. 2010-26.

[39] Dorich, J., M. Johnston, R. Mendes, S. Murchison, and Y. Zhang (2013). "ToTEM II: An Updated Version of the Bank of Canada's Quarterly Projection Model," Bank of Canada Technical Report No. 100.

[40] Farhi, E., and J. Tirole (2012). "Collective Moral Hazard, Maturity Mismatch, and Systemic Bailouts," American Economic Review, 102, 60-93.

[41] Faruqui, U., X. Liu, and T. Roberts (2012). "An Improved Framework for Assessing the Risks Arising from Elevated Household Debt," Bank of Canada Financial System Review (June): $51-57$.

[42] Galati, G., and R. Moessner (2010). "Macroprudential Policy - a literature review," BIS Working Papers No. 337.

[43] Gali, J., and T. Monacelli (2005). "Monetary Policy and Exchange Rate Volatility in a Small Open Economy," Review of Economic Studies, 72, 707-734. 
[44] Garriga, C., R. Manuelli, and A. Peralta-Alva (2012). "A Model of Price Swings in the Housing Market," Federal Reserve Bank of St. Louis Working Paper No. 2012-022A.

[45] Gerali, A., S. Neri, L. Sessa, and F. Signoretti (2010). "Credit and banking in a DSGE model of the Euro area", Journal of Money Credit and Banking, 42, 107-141.

[46] Gertler, M., S. Gilchrist, and F. M. Natalucci (2007). "External Constraints on Monetary Policy and the Financial Accelerator," Journal of Money, Credit and Banking, 39, 295-330.

[47] Gertler, M., and P. Karadi (2011). "A Model of Unconventional Monetary Policy," Journal of Monetary Economics, 58, 17-34.

[48] Gertler, M. and N. Kiyotaki (2010). "Financial Intermediation and Credit Policy in Business Cycle Analysis," Handbook of Monetary Economics, vol. 3, 547-599.

[49] Gilchrist, S., A. Ortiz, and E. Zakrajšek (2009). "Credit Risk and the Macroeconomy: Evidence from an Estimated DSGE Model," mimeo, Boston University.

[50] Granziera, E., and S. Kozicki (2012). "House Price Dynamics: Fundamentals and Expectations," Bank of Canada Working Paper No. 2012-12.

[51] Greenwood, J., and B. Jovanovic (1999). "The Information-Technology Revolution and the Stock Market," American Economic Review, 89, 116-122.

[52] Holmstrom, B. and J. Tirole (1997). "Financial intermediation, loanable funds and the real sector," Quarterly Journal of Economics, 112, 663-691.

[53] Iacoviello, M. (2005). "House Prices, Borrowing Constraints, and Monetary Policy in Business Cycles," American Economic Review, 95, 739-764.

[54] Iacoviello, M. (2013). "Financial Business Cycles," mimeo, Federal Reserve Board.

[55] Iacoviello, M., and S. Neri (2010). "Housing Market Spillovers: Evidence from an Estimated DSGE Model," American Economic Journal: Macroeconomics, 2, 125-164.

[56] Jermann, U. J., and V. Quadrini (2012). "Macroeconomic Effects of Financial Shocks," American Economic Review, 102, 238-271. [erratum: AER, 102, 1186].

[57] Kareken, J. H., and N. Wallace (1978). "Deposit Insurance and Bank Regulation: A PartialEquilibrium Exposition," Journal of Business, 51, 413-438.

[58] Kiyotaki, N., and J. Moore (1997). "Credit Cycles," Journal of Political Economy, 105, 211-48.

[59] Kiyotaki, N., and J. Moore (2012). "Liquidity, Business Cycles, and Monetary Policy," NBER Working Paper No. 17934. 
[60] Leeper, E. M., M. Plante, and N. Traum (2010). "Dynamics of fiscal financing in the United States," Journal of Econometrics, 156, 304-321.

[61] McGrattan, E. R., and E. C. Prescott (2005). "Taxes, Regulations, and the Value of U.S. and U.K. Corporations," Review of Economic Studies, 72, 767-796.

[62] Meh, C., and K. Moran (2010). "The Role of Bank Capital in the Propagation of Shocks," Journal of Economic Dynamics and Control, 34, 555-576.

[63] Murchison, S., and A. Rennison (2006). "ToTEM: The Bank of Canada's New Quarterly Projection Model," Bank of Canada Technical Report No. 97.

[64] Rajan, R. G. (2006). "Has Finance Made the World Riskier?," European Financial Management, $12,499-533$.

[65] Rotemberg, J. J. (1982). "Monopolistic Price Adjustment and Aggregate Output," Review of Economic Studies, 49, 517-31.

[66] Schmitt-Grohe, S. and M. Uribe (2003). "Closing Small Open Economy Models," Journal of International Economics, 61, 163-185.

[67] Shiller, R. (2000). Irrational Exuberance, Princeton University Press (second edition 2005).

[68] Smets, F., and R. Wouters (2007). "Shocks and Frictions in US Business Cycles: A Bayesian DSGE Approach," American Economic Review, 97, 586-606.

[69] Van den Heuvel, S. J. (2008). "The welfare cost of bank capital requirements," Journal of Monetary Economics, 55, 298-320.

[70] Woodford, M. (2001). "Fiscal Requirements for Price Stability," Journal of Money, Credit and Banking, 33, 669-728.

[71] Woodford, M. (2012). "Inflation Targeting and Financial Stability," NBER Working Paper No. 17967. 


\begin{tabular}{lcc}
\hline \hline Table 1. Parameters & & \\
\hline \hline & Symbol & Value \\
\hline Discount factor & $\beta_{P}, \beta_{B}, \beta_{I}, \beta_{E}$ & $0.993,0.9920 .987,0.988$ \\
Inverse labor supply elasticity & $\vartheta$ & 5 \\
Habit in consumption & $\zeta$ & 0.94 \\
Level for housing in utility & $\xi_{h P}, \xi_{h I}$ & $3.1,4.1$ \\
Level for labor in utility & $\xi_{l P}, \xi_{l I}$ & $11.2,11.2$ \\
\hline Depreciation rate & $\delta_{h}, \delta_{k}$ & $0.011,0.015$ \\
Capital share in production & $\alpha$ & 0.3 \\
Patient HH share in K and L & $\mu_{k}, \mu_{l}$ & $0.43,0.68$ \\
Import share in final goods & $\phi_{c}, \phi_{i k}, \phi_{i h}, \phi_{g}, \phi_{x}$ & $0.3,0.18,0,0.08,0.33$ \\
EOS - domestic and foreign goods & $\eta_{c}, \eta_{i k}, \eta_{i h}, \eta_{g}, \eta_{x}$ & $0.5,0.5,0.5,0.5,0.5$ \\
Export demand (habit, elast., share) & $\zeta^{*}, \eta^{*}, \phi^{*}$ & $0.8,1.5,0.32$ \\
\hline Wage and price and markup & $\theta_{w}, \theta_{d}, \theta_{m}, \theta_{x}$ & 1.25 \\
Wage and price stickiness & $\kappa_{w}, \kappa_{d}, \kappa_{m}, \kappa_{x}$ & $333,84,84,2$ \\
Wage and price indexation & $\varsigma_{w}, \varsigma_{d}, \varsigma_{m}, \varsigma_{x}$ & $0.5,0.5,0.5,0.5$ \\
Utilization cost - elasticity & $\varpi \varpi$ & 5 \\
Investment adj. cost & $\kappa_{h}, \kappa_{k}$ & 6,6 \\
Stock adj. cost & $\kappa_{h P}, \kappa_{k P}$ & 50,50 \\
\hline Coupon rates on long-term loans & $\delta_{I}, \delta_{E}$ & $0.97,0.92$ \\
Dividend adj. costs & $\kappa_{d B}, \kappa_{d E}$ & 50,50 \\
Monitoring cost elasticity & $\chi_{d 2}, \chi_{I 2}, \chi_{E 2} ; \chi_{d 3}$ & $0.002,0.005,0.05 ; 0.01$ \\
Portfolio preference term & $\varrho_{\varkappa}, \gamma$ & 0.1 \\
Regulatory LTV and capital ratio & $m_{I}, a_{y}$ & $0.75,2.5,0$ \\
Taylor rule & & \\
\hline \hline
\end{tabular}




\begin{tabular}{lcc}
\hline \hline \multicolumn{2}{l}{ Table 2. Model steady-state ratios } & \\
\hline \hline Consumption / GDP & Symbol & Model \\
Business investment /GDP & $c / y$ & 0.583 \\
Residential investment /GDP & $i_{k} / y$ & 0.122 \\
Government exp. / GDP & $i_{h} / y$ & 0.065 \\
Exports / GDP (= Imports / GDP $)$ & $g / y$ & 0.230 \\
\hline Capital stock / GDP (qrt.) & $y_{x} / y=y_{m} / y$ & 0.320 \\
Housing stock / GDP (qrt.) & $k / y$ & 8.0 \\
\hline Wage share in total income & $h / y$ & 6.0 \\
Wage share of impatient hh. & $1-\alpha$ & 0.7 \\
Consumption share of impatient hh. & $1-\mu_{l}$ & 0.32 \\
Housing share of impatient hh. & $c_{I} / c$ & 0.32 \\
Capital share of entrepreneurs & $h_{I} / h$ & 0.32 \\
\hline Business debt / total capital & $k_{E} / k$ & 0.5 \\
$\quad$ for entrepreneurs only & $p_{E} b_{E} / k$ & 0.25 \\
Mortgage debt / total housing & $p_{E} b_{E} / k_{E}$ & 0.5 \\
for impatient hh. only & $p_{I} b_{I} / h$ & 0.3 \\
Bank capital ratio & $p_{I} b_{I} / h_{I}$ & 0.95 \\
\hline \hline
\end{tabular}

\begin{tabular}{lccc}
\hline \hline \multicolumn{4}{c}{ Table 3. Comparing peak effects of macroprudential and monetary policies (in pp) } \\
\hline \hline & $5 \mathrm{pp} \downarrow$ in LTV & $1 \mathrm{pp} \uparrow$ in cap. req. & $100 \mathrm{bp} \uparrow$ in policy rate \\
\hline Output & -0.67 & -0.35 & -0.44 \\
Consumption & -0.50 & -0.10 & -0.16 \\
Business inv. & -0.87 & -2.68 & -1.35 \\
Residential inv. & -11.56 & -2.58 & -1.78 \\
Inflation & -0.14 & -0.07 & -0.16 \\
\hline House price & -5.54 & -1.21 & -1.50 \\
Household debt & -7.60 & -1.37 & -0.50 \\
\hline \hline
\end{tabular}




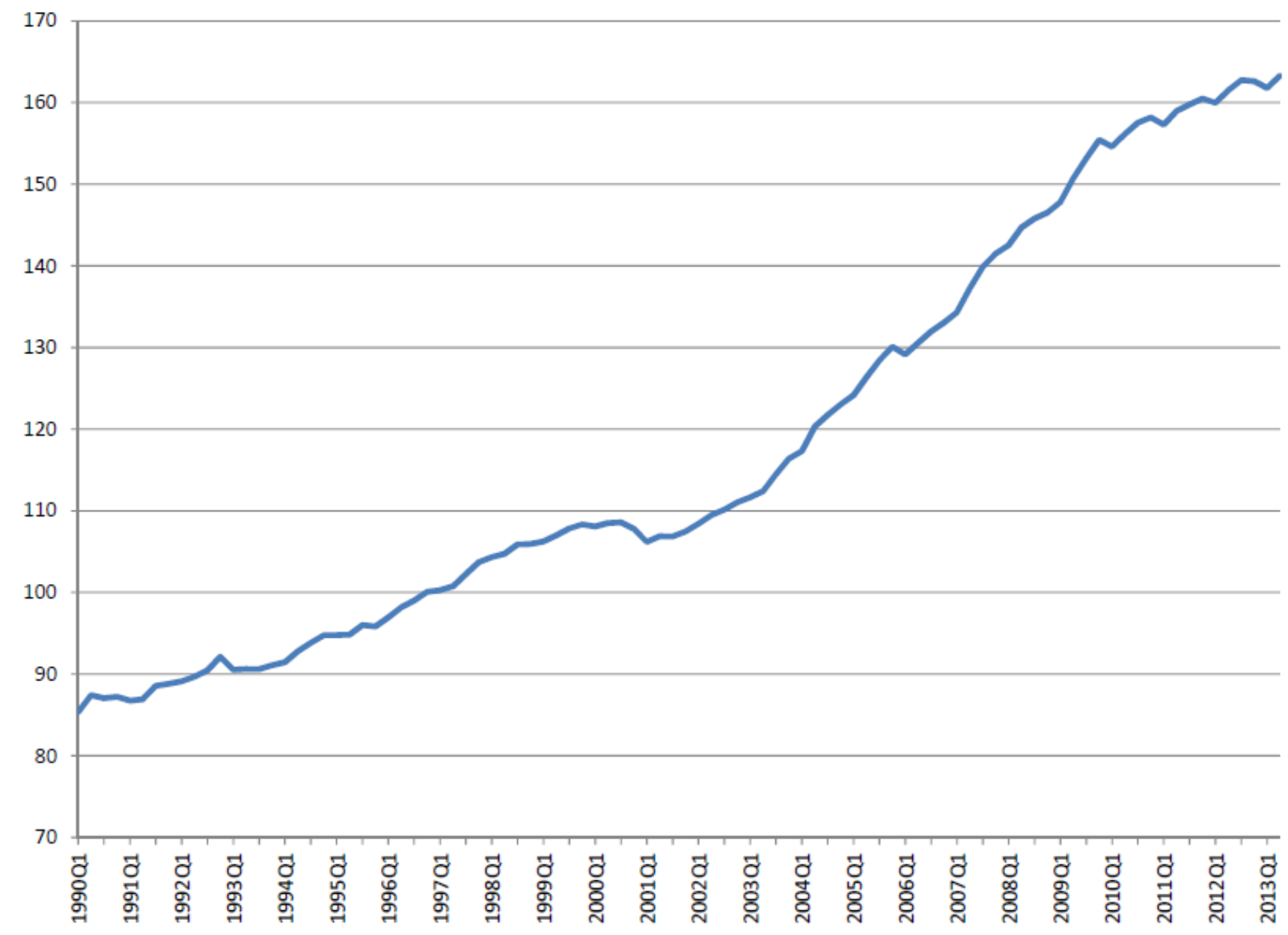

Figure 1: Household debt (as per cent of disposable income) in Canada 


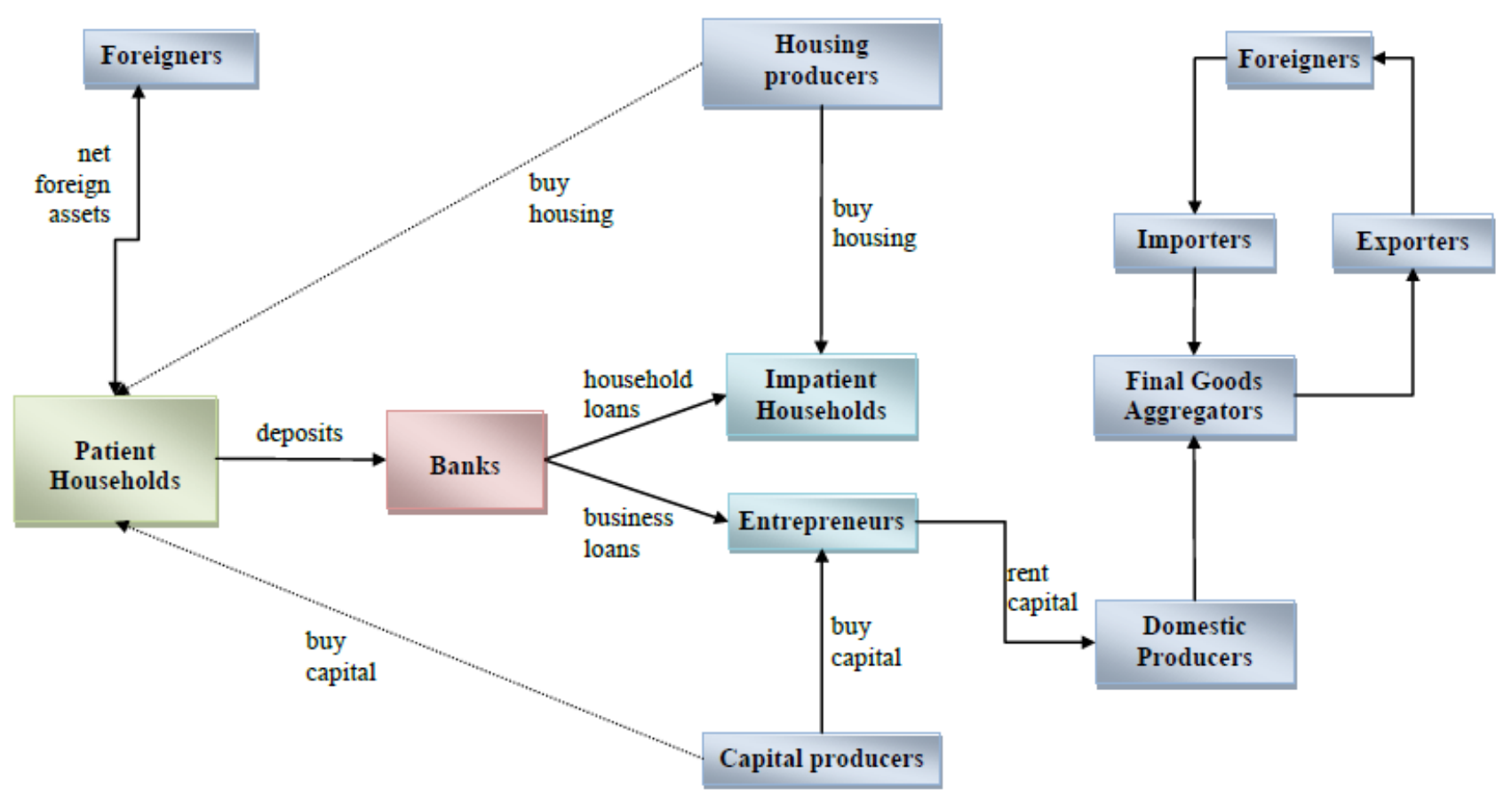

Figure 2: Model agents and key flows of funds, inputs and goods 

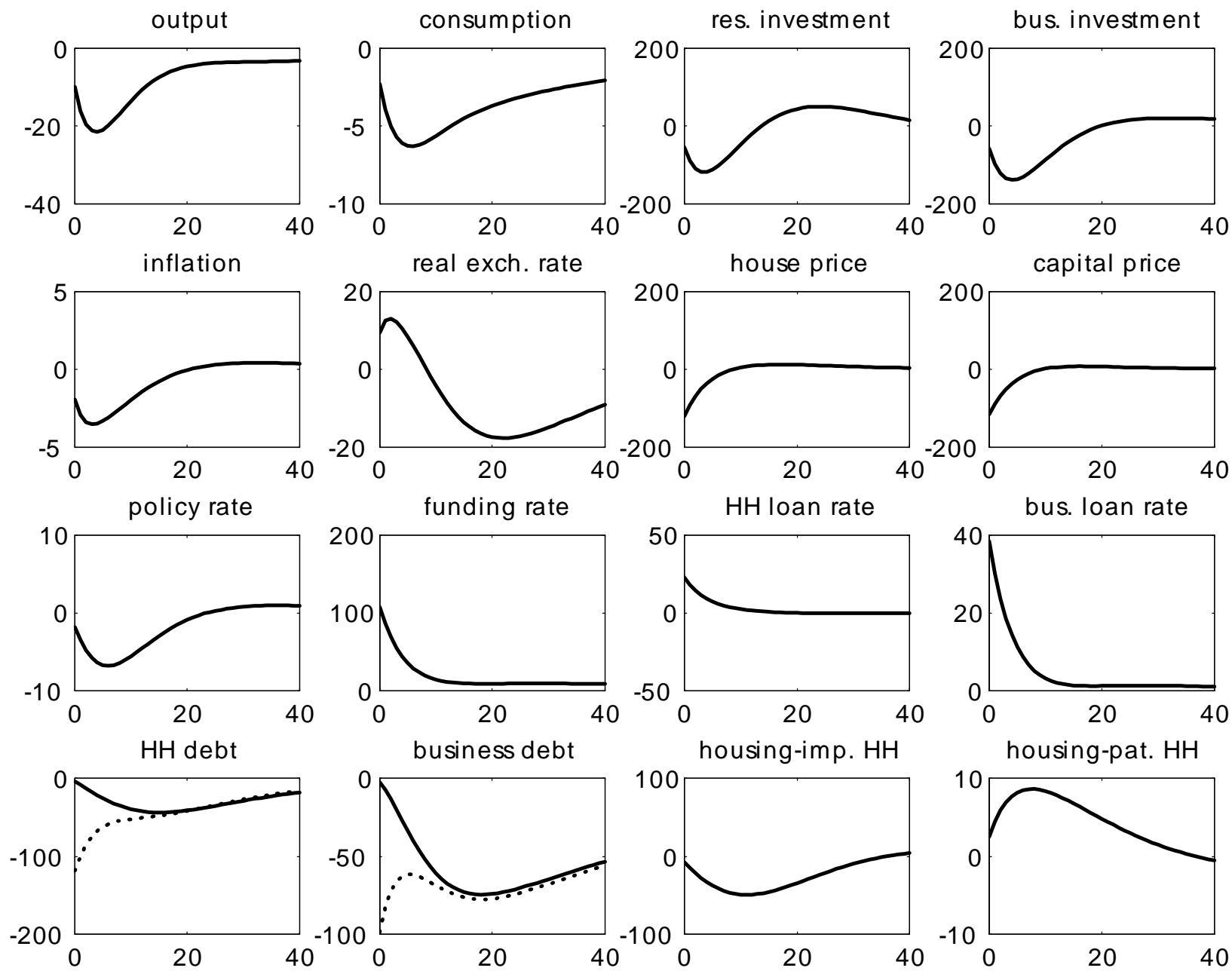

Figure 3: The effects of an exogenous increase in the funding spread (in bp). For household and business debt, the quantity of loans, $b_{I, t}$ and $b_{E, t}$, are indicated by solid lines, while the market value of loans, $p_{I, t} b_{I, t}$ and $p_{E, t} b_{E, t}$, are indicated by dotted lines. 

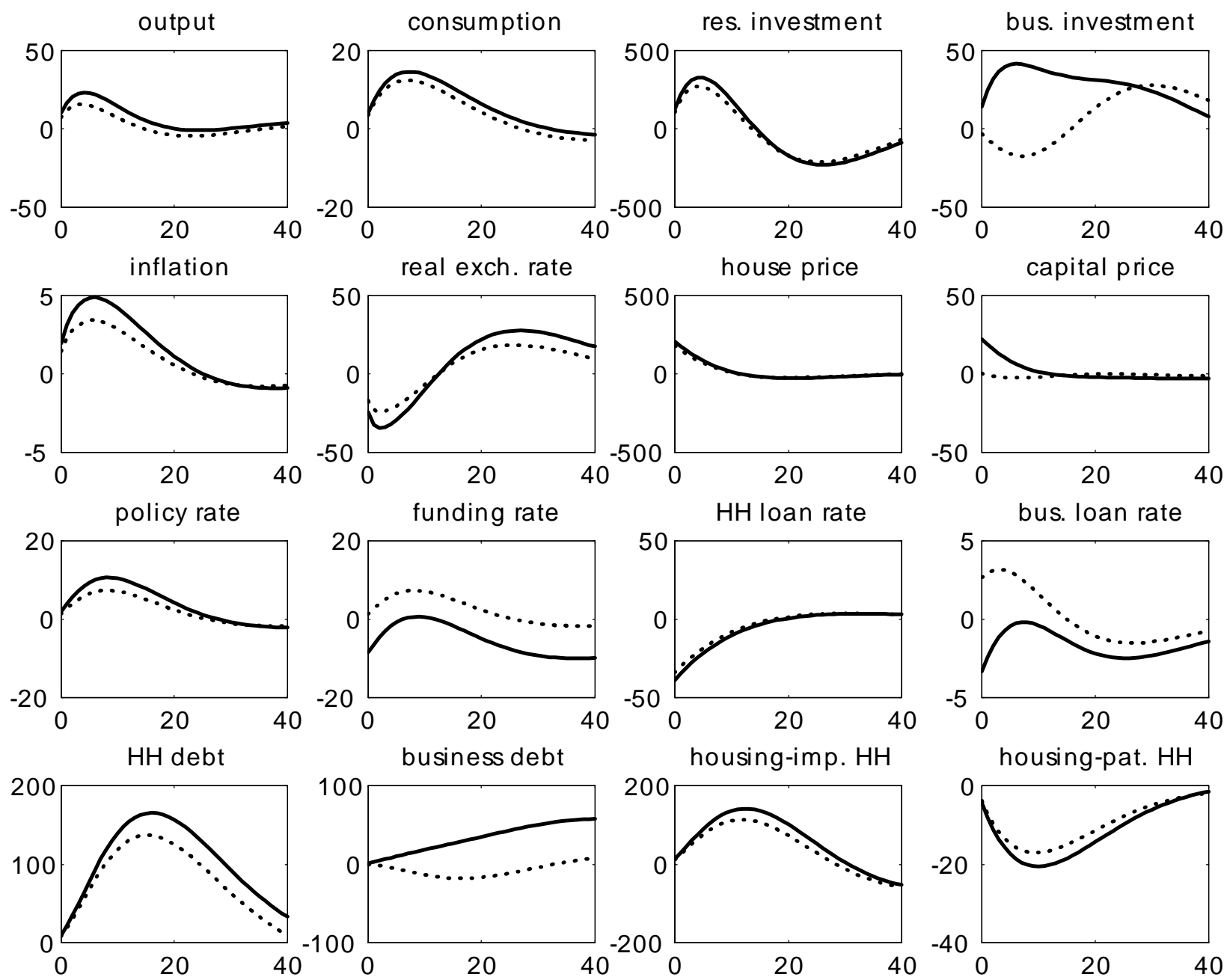

Figure 4: The effects of an exogenous decrease in the mortgage spread (in bp). The benchmark model with the bank capital channel is indicated by solid lines, while the alternative without the bank capital channel is indicated by dotted lines. 

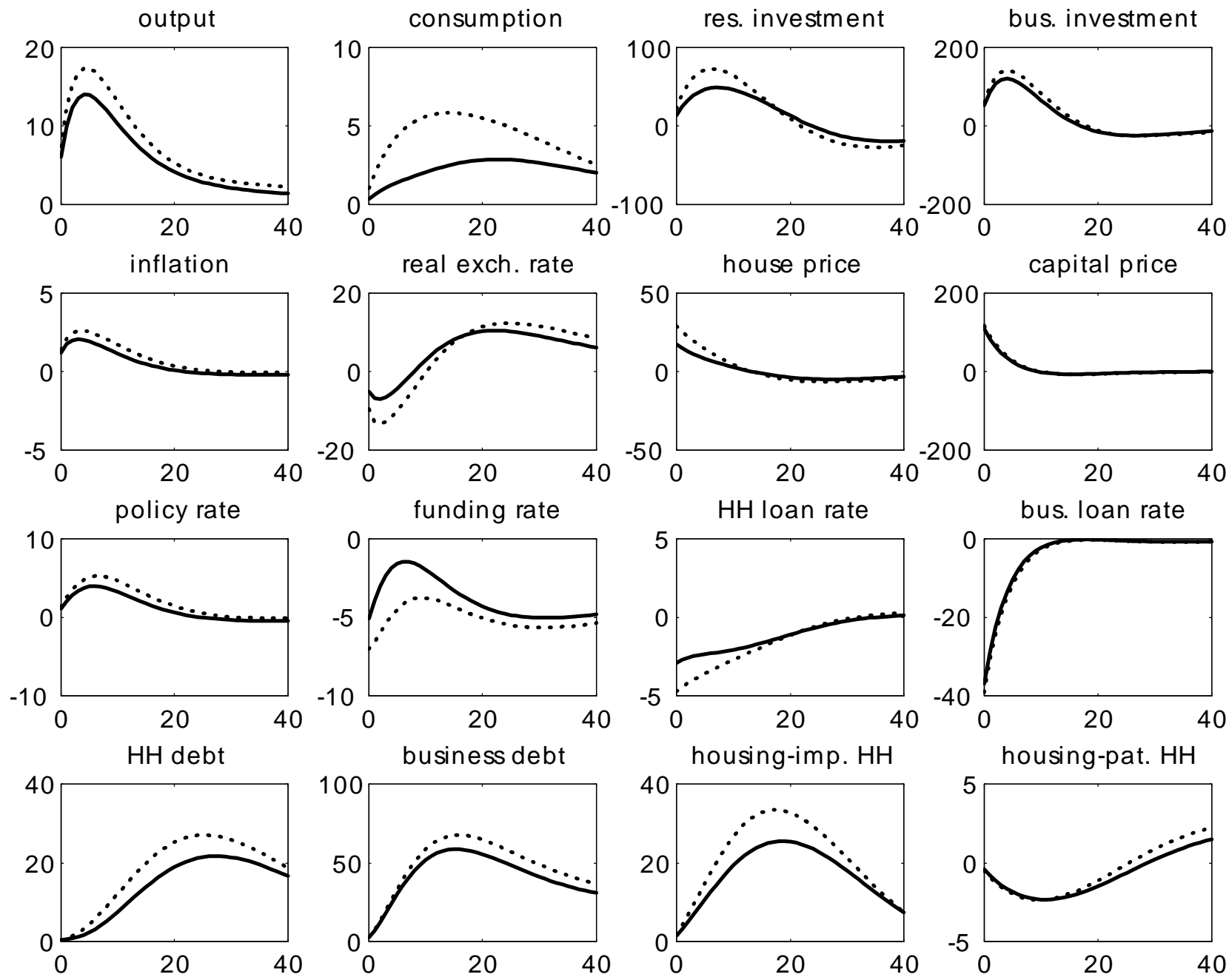

Figure 5: The effects of an exogenous decrease in the business loan spread (in bp). The benchmark model without the risk-taking channel is indicated by solid lines, while the alternative with the risk-taking channel is indicated by dotted lines. 

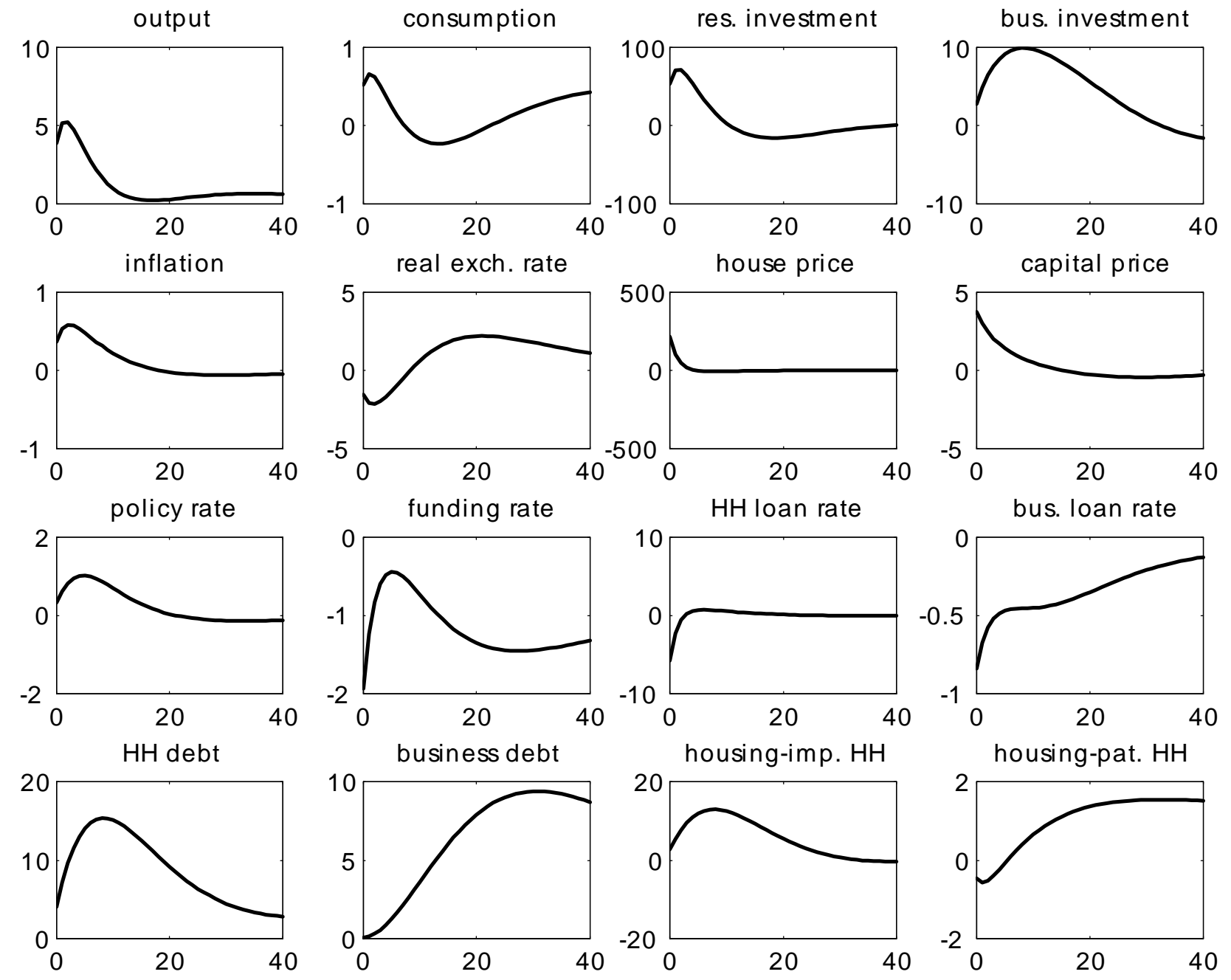

Figure 6: Effects of 1 per cent shock to exuberance in housing (in bp) 

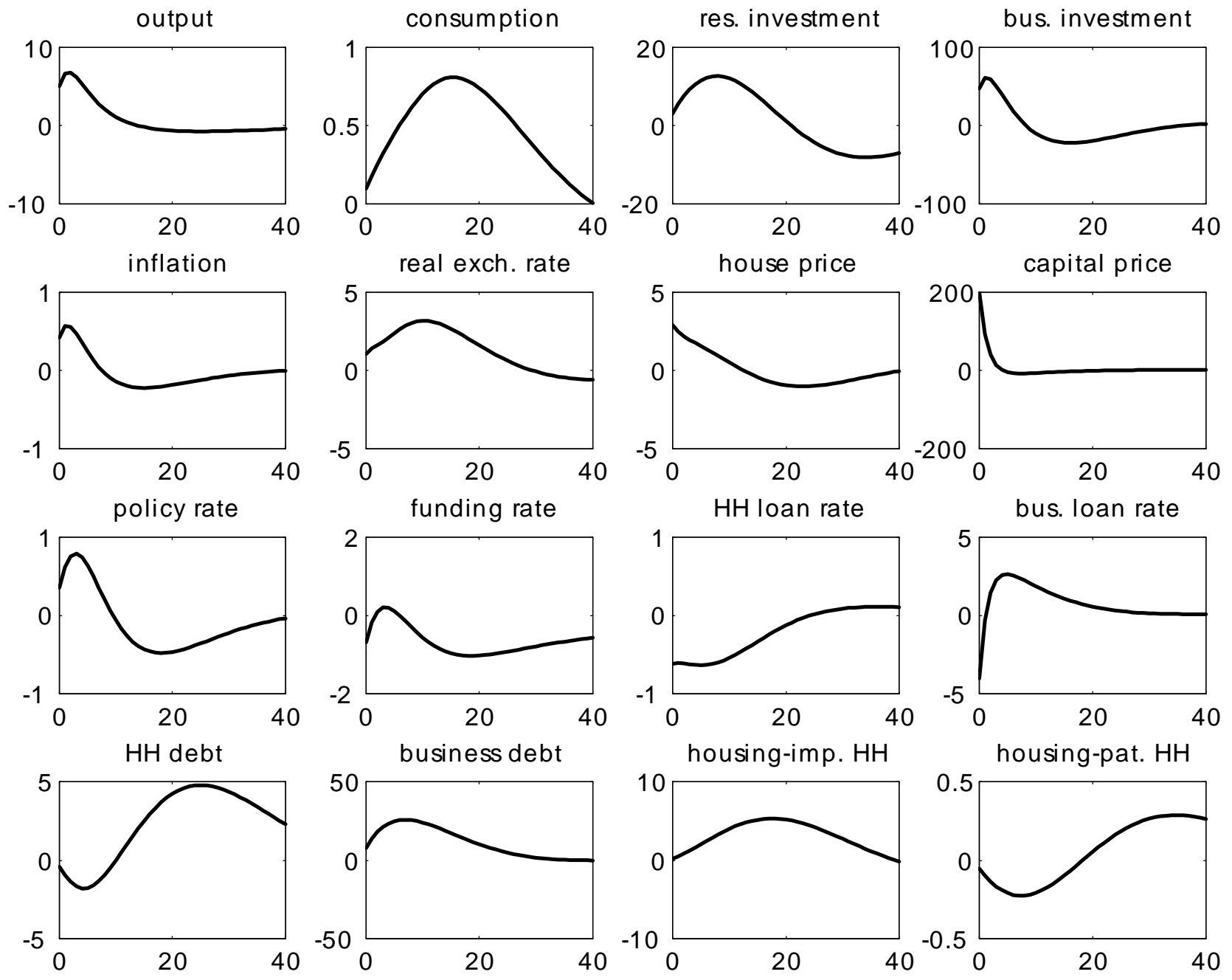

Figure 7: Effects of 1 per cent shock to exuberance in capital (in bp) 

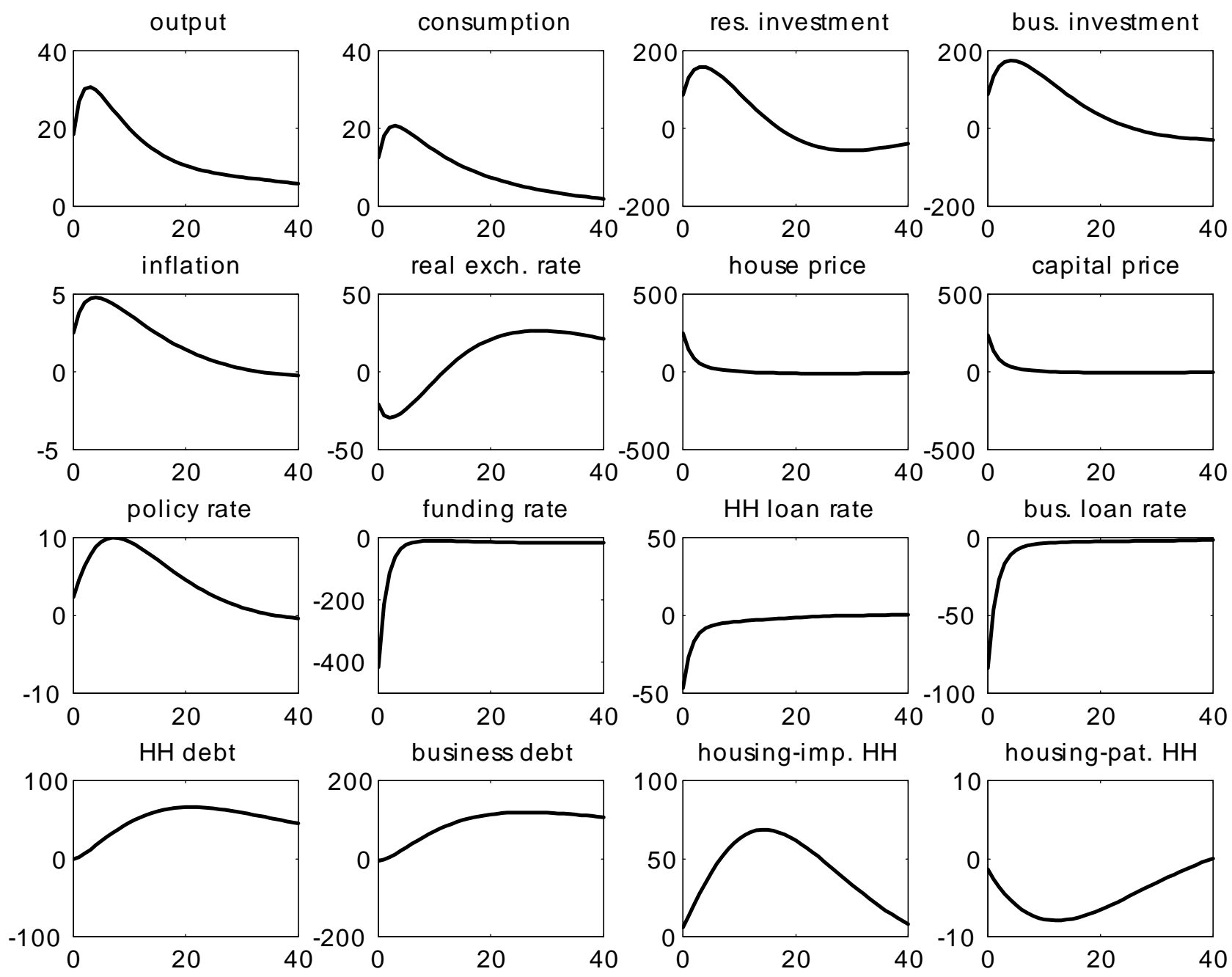

Figure 8: Effects of 1 per cent shock to the risk appetite of patient households (in bp) 

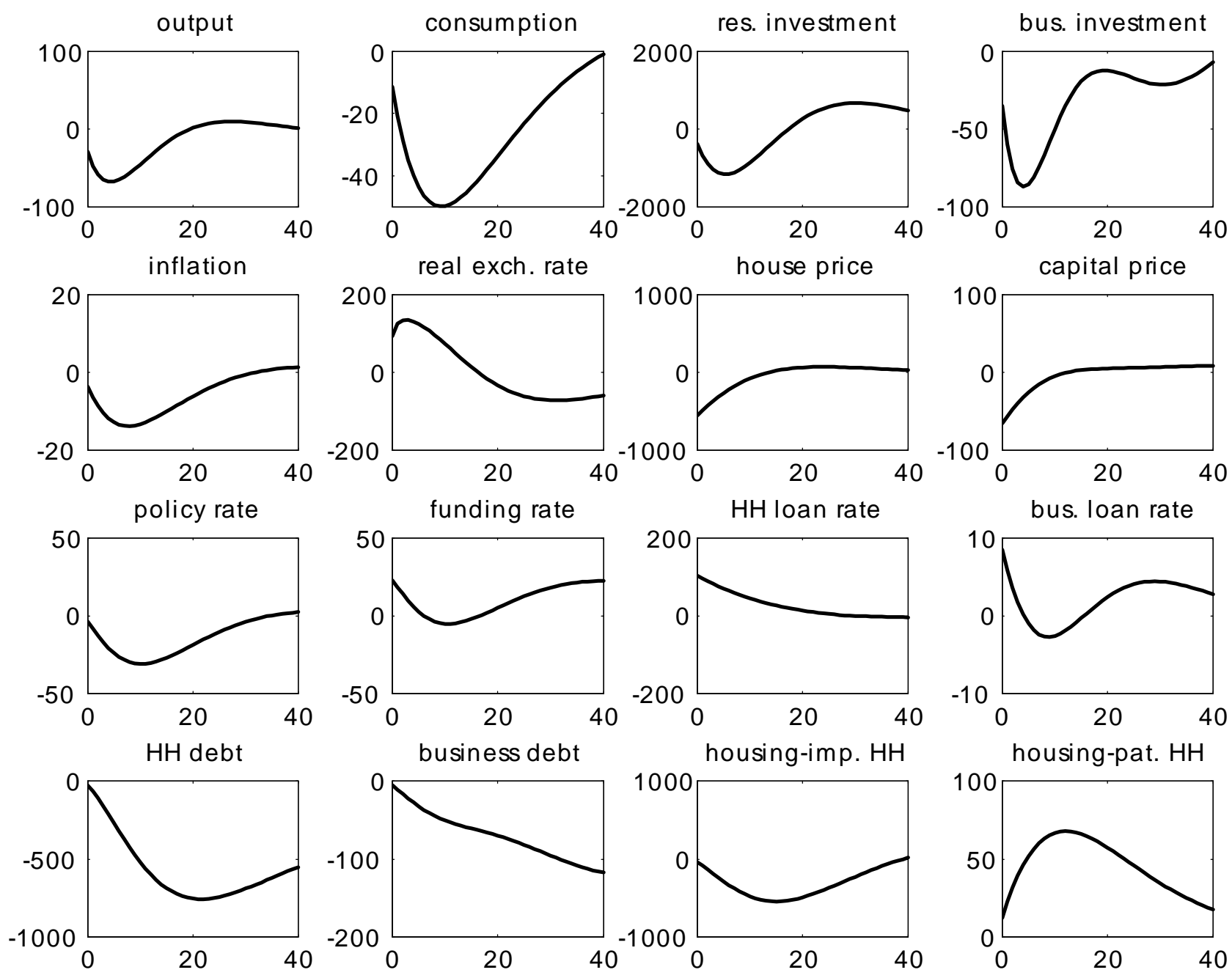

Figure 9: Effects of 5 pp decrease in regulatory LTV ratio (in bp) 

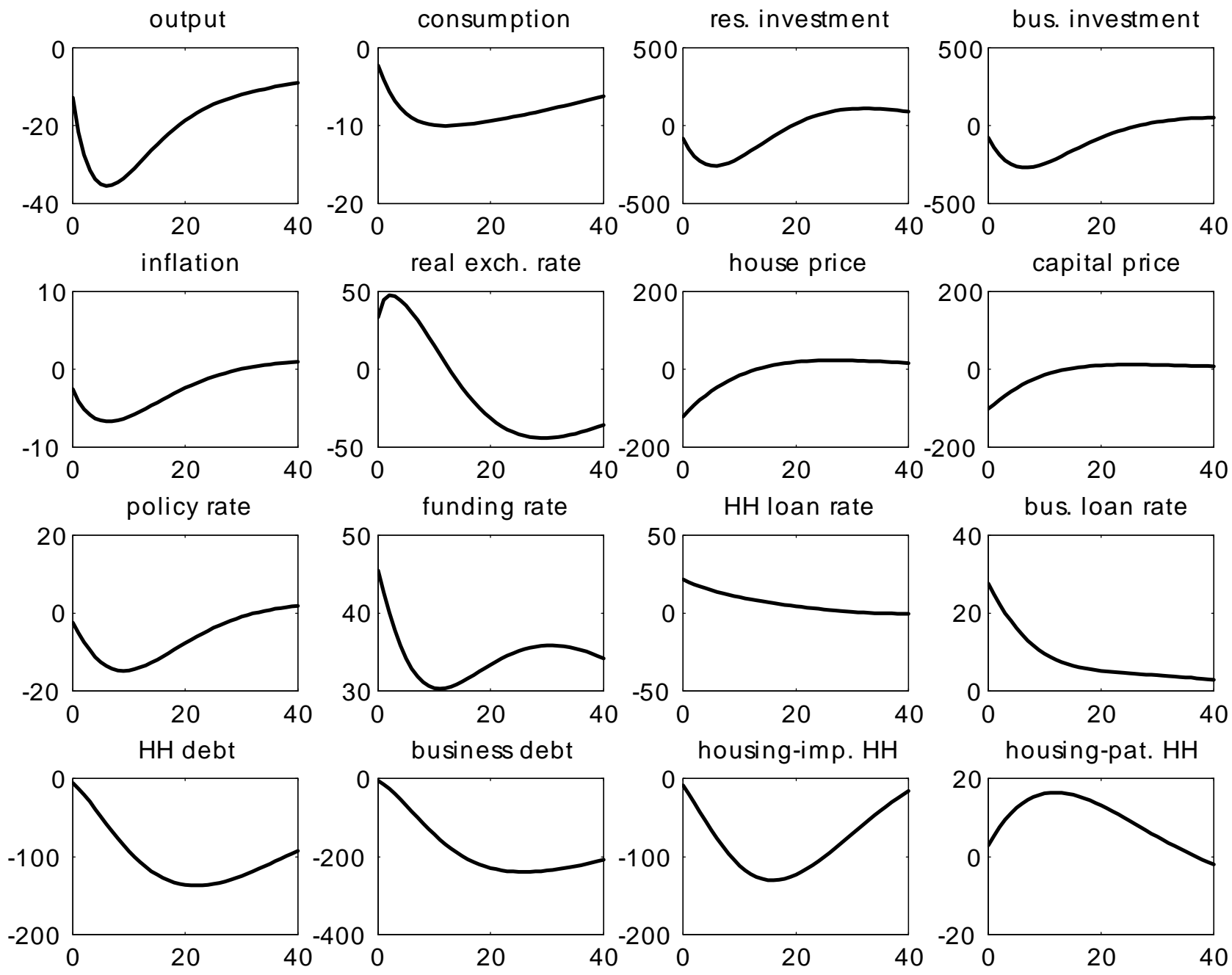

Figure 10: Effects of 1 pp increase in the capital requirement ratio (in bp) 

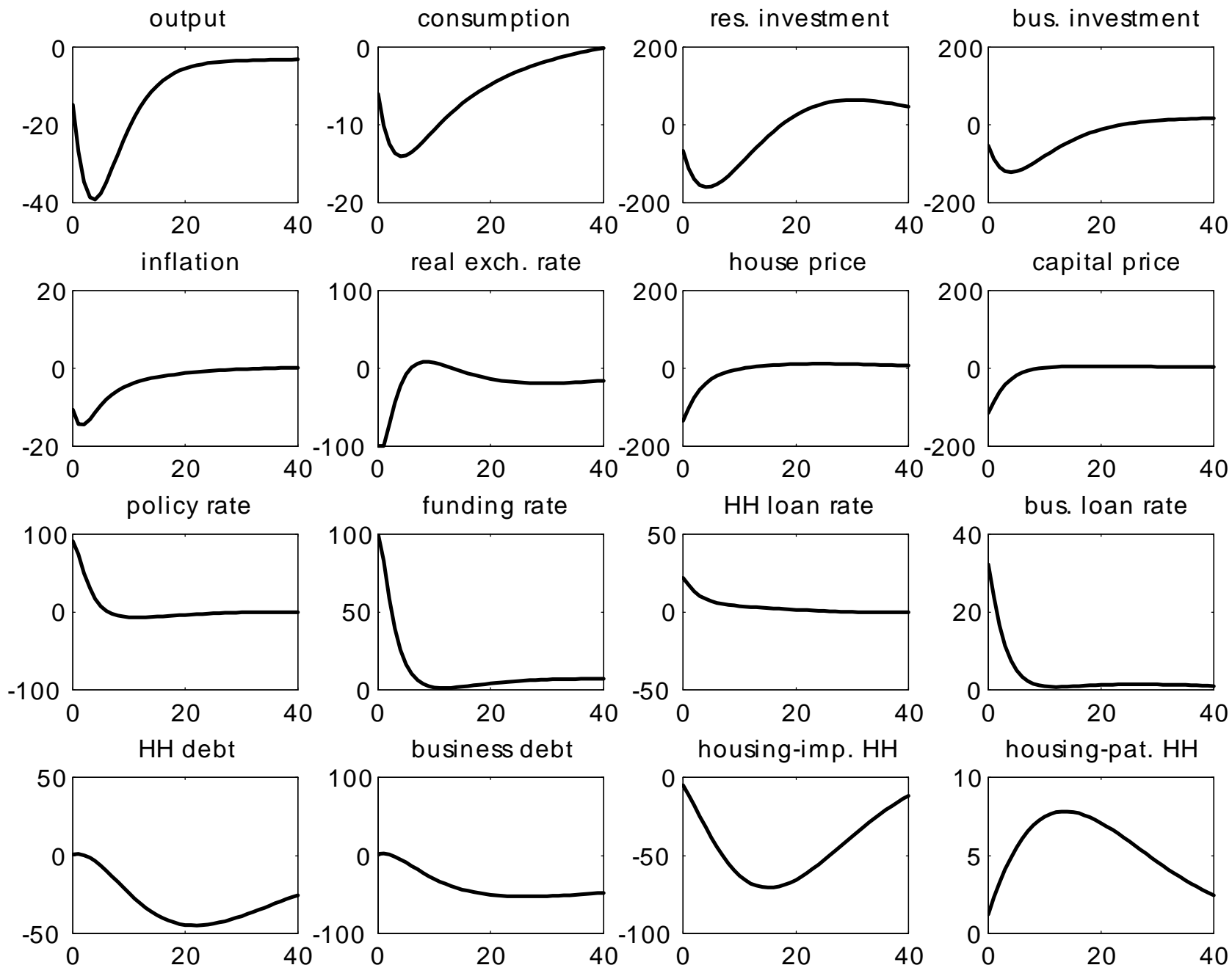

Figure 11: Effects of 100 bp (annualized) shock to the policy rate (in bp) 